\title{
Interrogating Host Antiviral Environments Driven by Nuclear DNA Sensing: A Multiomic Perspective
}

\author{
Timothy R. Howard and Ileana M. Cristea * \\ Department of Molecular Biology, Princeton University, Washington Road, Princeton, NJ 08544, USA; \\ th12@princeton.edu \\ * Correspondence: icristea@princeton.edu; Tel.: +1-609-258-9417
}

Received: 12 November 2020; Accepted: 23 November 2020; Published: 24 November 2020

\begin{abstract}
Nuclear DNA sensors are critical components of the mammalian innate immune system, recognizing the presence of pathogens and initiating immune signaling. These proteins act in the nuclei of infected cells by binding to foreign DNA, such as the viral genomes of nuclear-replicating DNA viruses herpes simplex virus type 1 (HSV-1) and human cytomegalovirus (HCMV). Upon binding to pathogenic DNA, the nuclear DNA sensors were shown to initiate antiviral cytokines, as well as to suppress viral gene expression. These host defense responses involve complex signaling processes that, through protein-protein interactions (PPIs) and post-translational modifications (PTMs), drive extensive remodeling of the cellular transcriptome, proteome, and secretome to generate an antiviral environment. As such, a holistic understanding of these changes is required to understand the mechanisms through which nuclear DNA sensors act. The advent of omics techniques has revolutionized the speed and scale at which biological research is conducted and has been used to make great strides in uncovering the molecular underpinnings of DNA sensing. Here, we review the contribution of proteomics approaches to characterizing nuclear DNA sensors via the discovery of functional PPIs and PTMs, as well as proteome and secretome changes that define a host antiviral environment. We also highlight the value of and future need for integrative multiomic efforts to gain a systems-level understanding of DNA sensors and their influence on epigenetic and transcriptomic alterations during infection.
\end{abstract}

Keywords: DNA sensing; IFI16; cGAS; innate immunity; protein interactions; virus-host interactions; post-translational modifications; mass spectrometry; proteomics; transcriptomics

\section{Introduction}

Eukaryotic cells are relentlessly assailed by a myriad of pathogens, thereby needing to constantly evolve and expand their mechanisms for pathogen detection and host defense. During infection, pathogens bring foreign sugars, lipids, proteins, and nucleic acids into host cells. These foreign molecules can act as pathogen-associated molecular patterns (PAMPs), and the ability of the cell to detect them is critical for the initiation of host defense mechanisms and the inhibition of virus production and spread. Thus, cells utilize specialized proteins known as pattern-recognition receptors (PRRs) to detect PAMPs [1]. A common PAMP detected by host cells is the pathogenic double-stranded DNA (dsDNA) from bacteria, DNA viruses, and some RNA viruses (i.e., retroviruses) [2]. PRRs for dsDNA, known as DNA sensors, bind to the pathogenic DNA and initiate defense programs that include innate immune signaling, inflammatory responses, and apoptosis. It was long believed that DNA sensors can only function outside of the nucleus, in order to avoid recognition of self-DNA and spurious activation of immune responses. However, the majority of the known human dsDNA viruses replicate within the nucleus, thereby depositing their viral genomes in the nuclei of infected cells. Examples of nuclear-replicating DNA viruses are herpesviruses, such as herpes simplex virus type 1 (HSV-1), 
human cytomegalovirus (HCMV), and Kaposi's sarcoma-associated herpesvirus (KSHV). Herpesviruses are ancient viruses that arose hundreds of millions of years ago, having ample time to co-diverge with their hosts [3-5]. The co-evolution and co-adaptation of viruses with hosts are evidenced by the diversification of PRRs and their ligand-recognition abilities [6]. Indeed, research during the past decade has demonstrated the existence of PRRs that function in nuclear sensing of pathogenic DNA $[7,8]$.

To date, four proteins have been shown to have the ability to perform nuclear DNA sensing-in chronological order of discovery of nuclear function: interferon-inducible protein 16 (IFI16 [9-11]), interferon-inducible protein X (IFIX [12]), cyclic GMP-AMP synthase (cGAS [13-16]), and heterogeneous nuclear ribonucleoprotein A2/B1 (hnRNPA2B1 [17]). The structures of these four proteins and their currently understood mechanisms for induction of antiviral responses are illustrated in Figure 1. Each nuclear DNA sensor was shown to help to induce ifn $\beta$ expression, which in turn activates numerous critical antiviral signaling pathways in adjacent cells that aim to slow the spread of infection. Ifn $\beta$ expression is thought to rely primarily on a signaling axis involving the endoplasmic reticulum membrane protein stimulator of interferon genes (STING), although STING-independent signaling has also been proposed [18]. Activation of STING leads to the phosphorylation of TANK binding kinase 1 (TBK1), which in turn phosphorylates the interferon regulatory factor 3 (IRF3). IRF3 then dimerizes, shuttles into the nucleus, and binds to the interferon-stimulated response element upstream of ifn $\beta$ to transcriptionally activate the expression of antiviral cytokines [19-22].

IFI16 was discovered as a sensor ten years ago [9], becoming the first known nuclear DNA sensor. Both IFI16 and IFIX belong to the PYHIN family of proteins [12]. These DNA sensors consist of an N-terminal pyrin domain (PYD) [23] and either one (IFIX) or two (IFI16) C-terminal HIN-200 domains [24,25] (Figure 1A). The HIN-200 domains facilitate sequence-independent binding of the sensor to the viral DNA [25], while the PYD mediates homotypic oligomerization [26,27]. IFI16 was shown to bind incoming viral dsDNA at the nuclear periphery, immediately following the docking of the virus capsid at the nuclear pore, and the PYD was found to be necessary for the IFI16 recruitment to the nuclear periphery [15]. The IFI16 oligomerization upon binding to viral DNA and recruitment of other host factors is thought to build an antiviral scaffold capable of both activating immune signaling $[9,10,26,28,29]$ and suppressing viral transcription [29-32] (Figure 1B). A subset of IFI16 was shown to be able to shuttle between the nucleus and the cytoplasm to function in DNA sensing in a localization-dependent manner $[9,10]$. However, during the early stages of infection with nuclear-replicating viruses, IFI16 does not appear to move to the cytoplasm, remaining predominantly nuclear. Thus, a still unanswered question is how IFI16 communicates with STING or whether a STING-independent mechanism also contributes to if $n \beta$ induction.

IFIX was also shown to bind dsDNA in a sequence-independent manner and to help induce antiviral cytokine expression upon herpesvirus infection [12]. Furthermore, similar to IFI16, this PYHIN protein displayed pronounced ability to undergo nuclear oligomerization via its PYD [26] and was shown to also function in suppressing viral gene expression [33]. However, very few studies have so far focused on IFIX during infection, and the mechanisms involved in IFIX-mediated antiviral responses remain poorly understood.

The mechanism by which cytoplasmic cGAS induces STING activation is well defined. cGAS contains an NTase core domain (Figure 1A) that catalyzes the formation of $2^{\prime} 3^{\prime}$-cyclic GMP-AMP (cGAMP) (Figure 1B). After binding to dsDNA, cGAS dimerizes and initiates cGAMP production. This small molecule then binds to STING, causing a conformational change and dimerization that leads to TBK1 phosphorylation. The additional presence of cGAS in the nucleus has been initially the subject of debate, although it was shown to form a functional nuclear interaction with IFI16 [14]. However, in recent years, it has become accepted that cGAS indeed has nuclear localization in different cell types, and studies have characterized mechanisms that prevent its autoreactivity [34] or that underlie its nuclear function in inhibiting DNA damage repair [16,35]. 
Finally, the most recently discovered nuclear DNA sensor, the heterogeneous nuclear ribonucleoproteins A2/B1 (hnRNPA2B1), has classically been understood to play a role in transporting mRNA into the cytoplasm [36,37]. In 2019, it was found that, during HSV-1 infection, hnRNPA2B1 both facilitates the export of IFI16, cGAS, and STING mRNA molecules to the cytoplasm and binds viral DNA within the nucleus, shuttles to the cytoplasm, and activates STING-TBK1-IRF3 signaling [17].

A

IFI16

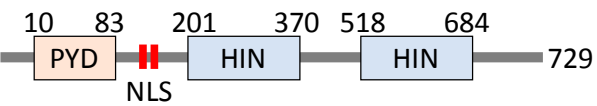

cGAS
IFIX

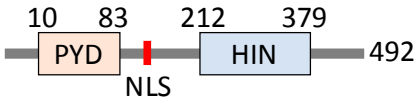

hnRNPA2B1

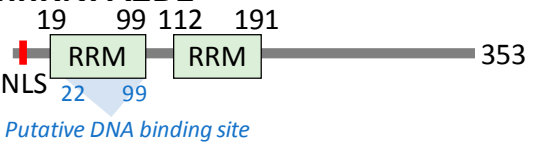

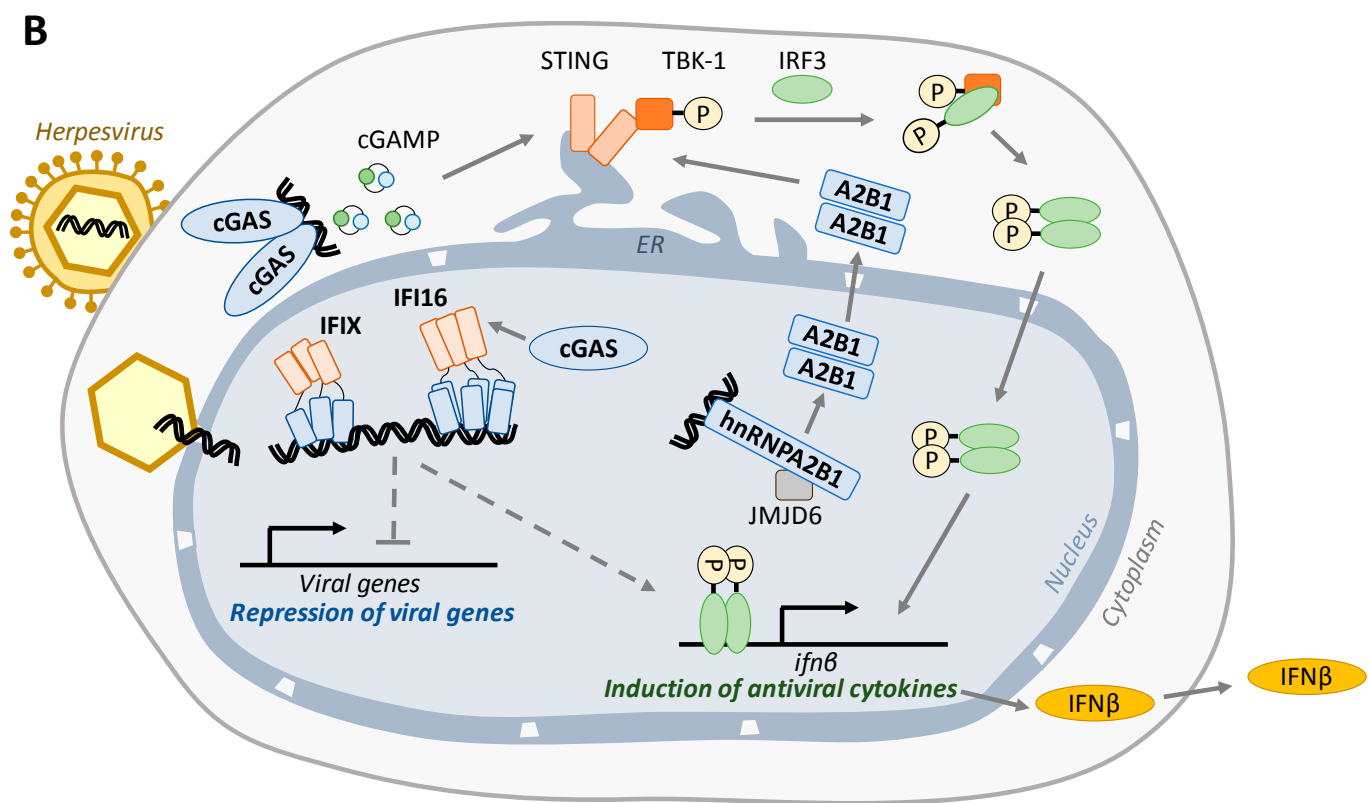

Figure 1. Nuclear DNA sensors bind to viral DNA and activate antiviral cytokine signaling. (A) Domain maps for each nuclear DNA sensor. IFI16 and IFIX belong to the PYHIN family of proteins and each contain an N-terminal pyrin domain that mediates protein interactions and one or two HIN-200 domains that bind dsDNA in a sequence-independent manner. cGAS consists of overlapping Ntase core (cGAMP production) and Mab21 (DNA binding) domains. hnRNPA2B1 possesses two RNA recognition motifs, the first of which has been proposed to also contain the DNA binding site. Each protein contains a nuclear localization signal (red bars). (B) Model for the intrinsic and innate immune activity of IFI16, IFIX, cGAS, and hnRNPA2B1. During infection, IFI16 and IFIX bind viral DNA entering the nucleus through a nuclear pore complex. After binding to viral DNA via their HIN domains (blue), these proteins each form homo-oligomers mediated by the PYD in order to build antiviral signaling scaffolds necessary for the repression of viral transcription and induction of IFNß. cGAS was shown to stabilize nuclear IFI16 levels during HSV-1 infection to promote immune signaling. In the cytoplasm, cGAS binds to foreign DNA and produces cGAMP, which in turn activates the STING-TBK1-IRF3 signaling axis to induce IFNB. hnRNPA2B1 binds viral DNA and is then demethylated by JMJD6. This is required for hnRNPA2B1 dimerization and subsequent translocation into the cytosol, where it activates the STING-TBK1-IRF3 axis. In each case, IFNß protein is secreted from the cell in order to communicate with and initiate antiviral programs in neighboring cells. 
The importance of these nuclear DNA sensors is highlighted by the various strategies acquired by viruses during their co-evolution with their hosts and adaptation to human cells to inhibit these DNA sensors and their antiviral functions. For example, HSV-1 promotes the degradation of IFI16 by targeting this pyrin domain. Several studies have showed this degradation to be primarily driven by the viral E3 ubiquitin ligase, ICP0 [12,15,28], while other studies suggested the contribution of other factors [38]. IFIX was also found to be degraded during HSV-1 infection, and this, yet to be discovered, inhibitory mechanism was shown not to be dependent on the ICP0 E3 ubiquitin ligase activity [33]. HSV-1 further utilizes the tegument protein pUL37 to suppress the cGAS-mediated catalysis of cGAMP through deamidation of a single arginine residue in the cGAS activation loop [39]. HCMV also acquired a mechanism to inhibit the function of nuclear sensors by preventing PYD oligomerization of IFI16 and IFIX [26]. This virus immune evasion strategy uses the major tegument protein of HCMV, pUL83, to clamp the PYD, block oligomerization, and inhibit subsequent immune signaling [26].

The mechanisms described above paint a picture of intricate signaling pathways that underlie the cellular intrinsic and innate immune systems that nuclear DNA sensors feed into and the opposing virus immune evasion strategies. On the host defense side, pathogenic DNA is bound by nuclear DNA sensors which then fulfill two roles: (1) activate immune programming and (2) suppress viral gene expression. These processes rely on interactions between biomolecules, are regulated by these interactions and post-translational modifications (PTMs) and affect the expression of hundreds of cellular and viral transcripts and proteins. Therefore, understanding nuclear DNA sensing requires a holistic approach in which all these factors are considered.

Knowledge of DNA sensor mechanisms is also relevant for understanding human diseases and the development of therapies. Dysregulation of DNA sensors contributes to several autoimmune disorders. For example, patients with systemic lupus erythematosus, Sjögren Syndrome, and systemic sclerosis exhibit significantly elevated levels of anti-IFI16 antibodies [40-42], which can result from aberrant overexpression and mislocalization of IFI16 [43]. Further, autoreactivity of cGAS contributes to Aicardi-Goutières syndrome (AGS) [44,45], and small molecule inhibition of cGAS activity alleviates constitutive interferon expression in an AGS mouse model [46]. Therefore understanding mechanisms regulating DNA sensors can provide important insights into driving factors of autoimmune disorders. Targeting DNA sensors or their activated pathways is also relevant in the development of both antiviral treatments and vaccines. For example, the STING-TBK1-IFN $\alpha / \beta$ signaling axis mediates the adjuvant effects required for successful immunogenicity with plasmid DNA vaccines [21,47]. Thus, we must consider how DNA sensors upstream of interferon induction react during the administration of DNA vaccines. So far, only the cytosolic PYHIN protein absent in melanoma 2 (AIM2), which directs the maturation of proinflammatory cytokines IL-18 and IL-1 $\beta$, has been demonstrated to act as a sensor for DNA vaccines [48]. Interestingly, immune responses elicited by DNA vaccines in vivo seem to be cGAS- and IRF3-independent [49]. Further investigations can help elucidate the relative contributions of these DNA sensors to aiding immune memory upon DNA vaccine administration.

Omic methods have significantly contributed to the emergence of the research field of nuclear DNA sensing, helping to build the current level of understanding of the underlying molecular mechanisms. Mass spectrometry (MS)-based proteomic approaches have allowed the discovery of functional regulatory hubs for nuclear DNA sensors, including protein interactions and PTMs, as well as the monitoring of DNA sensor activation (e.g., cGAMP production). Whole-cell proteome analyses and secretome investigations have informed of global cellular changes that take place during the host activation of immune signaling cascades. Transcriptome studies have started to uncover the contribution of some of these DNA sensors to repression of viral gene expression. Here, we review findings stemming from the application of proteomics and other omic methods to characterizing the function and regulation of nuclear DNA sensors and explore the future promise of multiomic approaches in understanding human immune responses to nuclear-replicating viral pathogens. 


\section{DNA Sensor Identification and Characterization through the Lens of Proteomics}

The use of proteomics directly led to the discovery of all known nuclear DNA sensors. As research into DNA sensing has intensified over the past decade, proteomics studies have been crucial for examining the functions and regulations of nuclear DNA sensors (Figure 2). These investigations have focused on proteome changes, protein-protein interactions (PPIs), and PTMs connected to nuclear DNA sensors in order to uncover the mechanisms of DNA sensing in response to viral infections. Here, we discuss the main MS-based approaches used for discovering DNA sensor interactions and PTMs that contribute to either promoting or inhibiting their host defense functions during viral infections (Table 1).

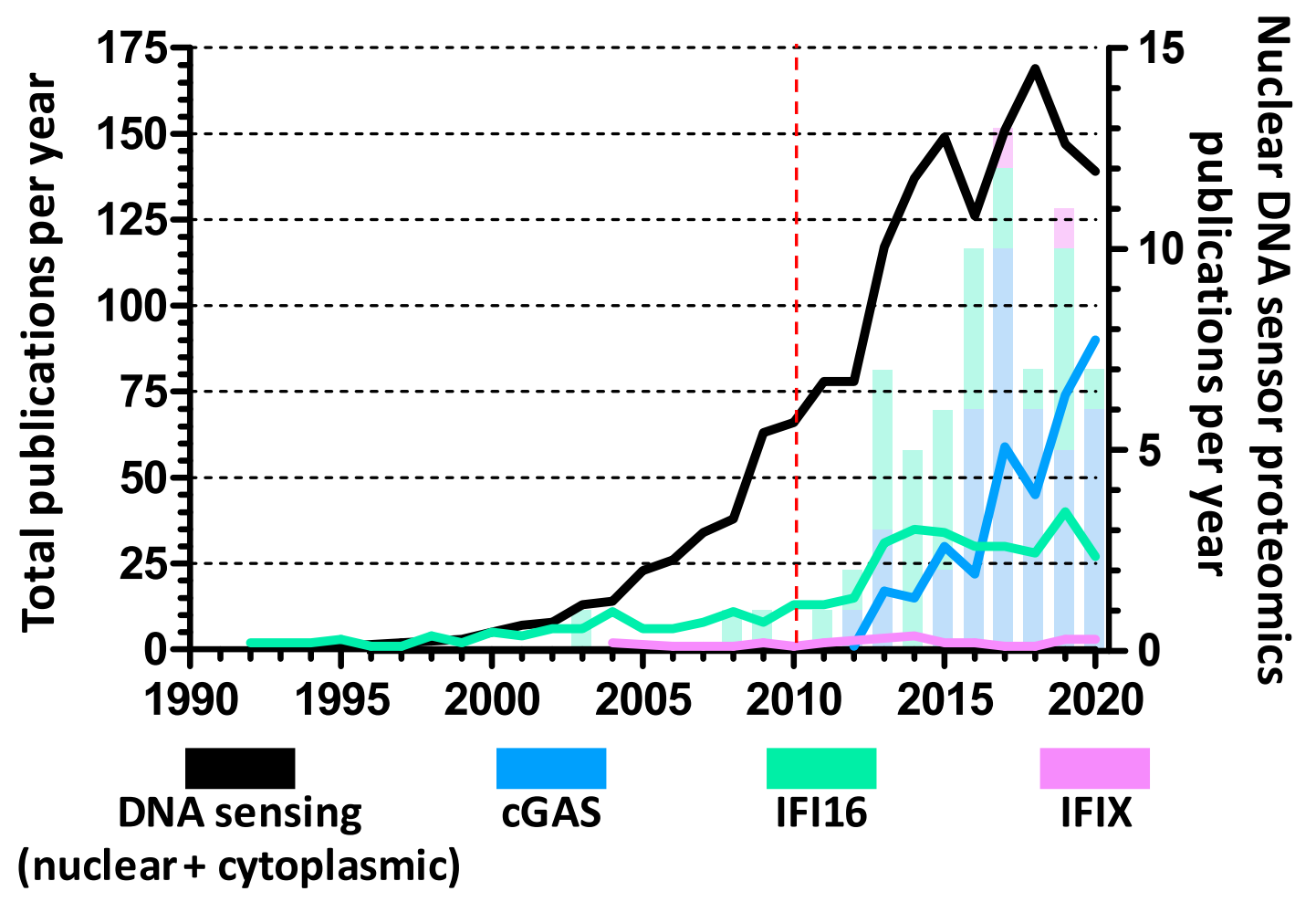

Figure 2. Yearly research articles investigating nuclear DNA sensors. Research papers focused on each nuclear DNA sensor, obtained from PubMed search when considering published research articles each year since 1990. The sum of each year's articles for each protein is represented by line graphs (left $Y$ axis) while articles specifically utilizing proteomics approaches to investigate proteome changes, protein-protein interactions, post-translational modifications, etc., are shown as stacked bars (right $Y$ axis). Of note, the black line represents the number of articles concerning all kinds of DNA sensing, including non-nuclear sensors such as the cytoplasmic AIM2 and endosomal TLR9. The red dashed line marks the discovery of IFI16 as the first nuclear DNA sensor. 
Table 1. Omics techniques used for the discovery and characterization of nuclear DNA sensors and related host antiviral processes.

\begin{tabular}{|c|c|c|c|c|c|}
\hline Strategy & Advantages & Disadvantages & Purpose & Application & References \\
\hline AP-MS isolating DNA & \multirow{4}{*}{$\begin{array}{l}\text { Unbiased detection of proteins } \\
\text { bound to DNA or to DNA sensor; } \\
\text { high sensitivity; enrichment of } \\
\text { proteins of interest; ability to } \\
\text { detect multiple PTM types }\end{array}$} & \multirow{4}{*}{$\begin{array}{l}\text { Could miss transient } \\
\text { interactions; does not } \\
\text { discriminate between } \\
\text { direct and indirect } \\
\text { interactions; nonspecific } \\
\text { interactions are possible }\end{array}$} & Identify DNA sensors & IFI16, hnRNPA2B1 & {$[9,17]$} \\
\hline \multirow{3}{*}{ IP-MS isolating DNA sensors } & & & Identify DNA sensors & IFIX & [12] \\
\hline & & & Interactome & $\begin{array}{l}\text { IFI16, IFIX, cGAS, } \\
\text { hnRNPA2B1 }\end{array}$ & {$[12,15,17,29,33,50,51]$} \\
\hline & & & PTMs & IFI16, cGAS & {$[10,52,53]$} \\
\hline \multirow{4}{*}{ Shotgun MS (whole proteome) } & \multirow{4}{*}{$\begin{array}{l}\text { High throughput, unbiased, } \\
\text { high sensitivity }\end{array}$} & \multirow{4}{*}{$\begin{array}{l}\text { Complex datasets; } \\
\text { computationally intensive; } \\
\text { possible missing values in } \\
\text { quantitative proteome } \\
\text { measurements }\end{array}$} & Identify DNA sensors & cGAS & [13] \\
\hline & & & Proteome & cGAS & [51] \\
\hline & & & Secretome & Herpesvirus infection & [54] \\
\hline & & & Metabolome & Herpesvirus infection & [55] \\
\hline \multirow{4}{*}{ Targeted MS } & \multirow{4}{*}{$\begin{array}{l}\text { High accuracy } \\
\text { and sensitivity; specific detection; } \\
\text { requires low sample amount }\end{array}$} & \multirow{4}{*}{$\begin{array}{l}\text { Needs prior detection or } \\
\text { defining signature } \\
\text { detection parameters; } \\
\text { needs specialized MS } \\
\text { instrumentation }\end{array}$} & Protein abundance & $\begin{array}{l}\text { Immune factor } \\
\text { quantification }\end{array}$ & [51] \\
\hline & & & Confirmation of protein interactions & cGAS, IFI16 & {$[14,29]$} \\
\hline & & & PTMs & cGAS & [53] \\
\hline & & & Small molecule detection & cGAMP & [13] \\
\hline DNA microarrays & $\begin{array}{l}\text { High throughput; inexpensive; } \\
\text { customizable to detect specific } \\
\text { sequences and isoforms }\end{array}$ & $\begin{array}{l}\text { High background noise; } \\
\text { requires high sample } \\
\text { amount; biased approach }\end{array}$ & Transcriptome & Herpesvirus infection & [56] \\
\hline RNA sequencing & $\begin{array}{l}\text { High throughput; unbiased; } \\
\text { requires low sample amount; } \\
\text { single base resolution }\end{array}$ & $\begin{array}{c}\text { Requires library } \\
\text { preparation; } \\
\text { computationally intensive; } \\
\text { expensive }\end{array}$ & Transcriptome & IFI16 (mouse homolog) & [57] \\
\hline
\end{tabular}




\subsection{DNA Sensor Molecular Interactions Drive Host Antiviral and Virus Immune Evasion Mechanisms}

Affinity purification-mass spectrometry (AP-MS) has been the cornerstone of identifying and quantifying protein-protein and protein-nucleic acid interactions [58]. In this approach, either a protein of interest or DNA is isolated and the accompanying interacting proteins are analyzed using mass spectrometry. Immunoaffinity purification (IP) is carried out by using an antibody conjugated to a resin, such as magnetic beads, which can be easily separated from the cell lysate and captured via centrifugation or application of a magnet (reviewed in [59]). The antibodies used can be raised against the endogenous protein of interest. However, as the efficiency and specificity of the isolation relies on the quality of the available antibody, antibodies against tags such as FLAG, HA, and GFP are often used to facilitate protein isolation [60]. DNA can be purified from cells through similar methods, usually using biotinylated DNA and streptavidin-coupled beads to isolate DNA-protein complexes [9]. Following complex isolation, the identities and abundances of the accompanying proteins are then characterized using MS.

It has long been understood that viral DNA activates innate immune responses, including ifn- $\beta$ expression [61], but the identities of the DNA sensors and subsequent signaling pathways remained undetermined. AP-MS approaches have been at the core of discovering the identities of DNA sensors. IFI16 was recognized as a DNA sensor in 2010, when Unterholzner et al. performed AP-MS after transfecting THP-1 cells with a biotinylated 70 base-pair vaccinia virus DNA fragment (VACV 70mer) [9]. It is of note that IFI16 is expressed and localized to both the nucleus and cytoplasm in macrophages such as the macrophage-like differentiated THP-1 cells. Further studies demonstrated that IFI16 has DNA sensor activity in the nucleus after different types of infections with nuclear-replication DNA viruses, including HSV-1 [9,10,28], KSHV [11], and HCMV [30], as well as after retrovirus infection, recognizing DNA intermediates of human immunodeficiency virus 1 (HIV-1) [6,62]. The interaction between IFI16 and HSV-1 DNA was also demonstrated in an elegant study that utilized 5-ethynyl-2' deoxycytidine (EdC) labeling of viral genomes coupled with AP-MS to investigate temporal viral genome-protein interactions. Here, IFI16 was found to associate with the viral genome by $2 \mathrm{~h}$ post-infection [63]. Recently, IFI16 was identified in an AP-MS study isolating the RNA genome of Chikungunya virus [64]. This is an unexpected finding as IFI16 has no known RNA sensing capability, but it implicates IFI16 in immune sensing pathways beyond dsDNA virus infection.

AP-MS was also integral in the discovery of the most recently identified nuclear DNA sensor, hnRNPA2B1, which was shown to function during HSV-1 infection [17]. In this study, HSV-1 genome biotinylation and AP-MS was integrated with a characterization of the nuclear and cytoplasmic proteomes following cellular fractionation. This allowed the authors to identify hnRNPA2B1 as a protein that both binds to viral DNA and shuttles to the nucleus to activate STING-TBK1-IRF3 signaling.

As nuclear DNA sensors do not directly stimulate interferon expression, interaction with other cellular proteins is crucial for initiating immune signaling pathways. Furthermore, the importance of PPIs in the regulation of immunity is highlighted by the virus-host protein interactions through which viruses inhibit DNA sensors. Thus, IP-MS studies that define the interactomes of DNA sensors have led to a better understanding of both their action and regulation.

The first interactome study of IFI16 during HSV-1 infection used AP-MS to characterize interactions with both endogenous and tagged IFI16 [50]. This study revealed IFI16 interactions with many cellular transcription and chromatin regulators, such as the upstream binding transcription factor (UBTF) and ND10 body components, as well as with the nuclear architecture proteins SUN1 and SUN2. Several viral proteins were also found to associate with IFI16 [50], including the E3 ubiquitin ligase ICP0 that was previously implicated in targeting IFI16 for degradation (Figure 3) [28]. Both UBTF and ND10 bodies (also known as PML nuclear bodies) were shown to function in host defense by repressing HSV-1 transcription $[65,66]$, and ND10 bodies were also found to be targeted for degradation by ICP0 [67]. 


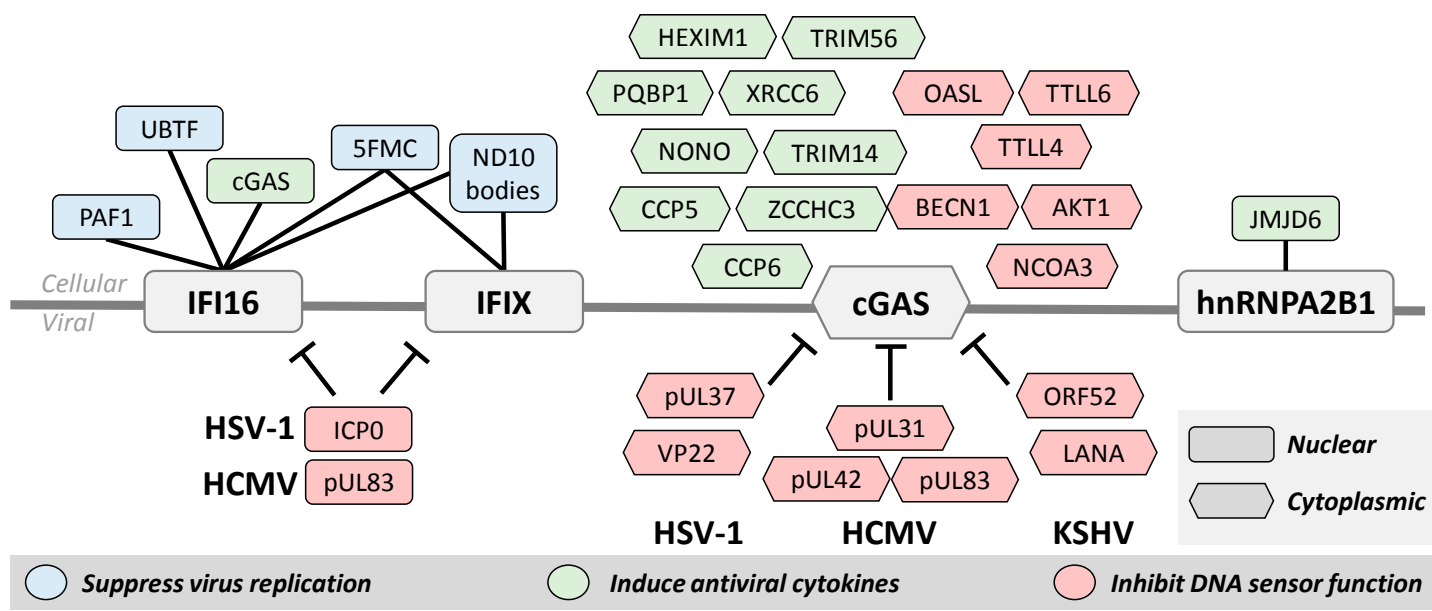

Figure 3. Protein-protein interactions contribute to the activation or inhibition of DNA sensor. Over the course of viral infection and immune signaling, DNA sensors interact with other cellular and viral proteins. Several of these cellular proteins are important for the function of the DNA sensors for both suppressing virus replication by repressing viral transcription and inducing antiviral cytokines. Protein interactions are also used to regulate DNA sensor function. Viruses have evolved distinct mechanisms to facilitate immune evasion and cells must also possess mechanisms to prevent excessive immune signaling. Although localized to both the nucleus and cytoplasm, protein interactions with cGAS are best characterized in the cytoplasm. Nuclear proteins are shown here as rectangles and cytoplasmic interactions as hexagons.

To further clarify how these interactions are facilitated and regulated during HSV-1 infection, the domain-specific interactomes of IFI16 were investigated by performing separate IP-MS experiments for the PYD and HIN domains [15]. This study revealed that the PYD interacts with members of ND10 bodies, cGAS, and the RNA polymerase II-associated factor 1 (PAF1). More recently, IP-MS with oligomerization-deficient IFI16 mutants demonstrated that IFI16 oligomerization is needed for the formation of these interactions with PAF1 and other members of the PAF1 complex during HSV-1 infection [29]. Additional experiments uncovered an antiviral role for PAF1, showing its ability to repress virus gene transcription.

Similar IP-MS interactome studies of PYHIN proteins related to IFI16 led to the discovery and characterization of IFIX as an antiviral nuclear DNA sensor [12]. At the time, very little was known about the cellular role of IFIX, but through IP-MS it was found to interact with many of the same proteins as IFI16, including ND10 body components and other chromatin remodeling and immune signaling proteins. These interactions, in conjunction with its structural similarities to IFI16, suggested that IFIX may also have antiviral properties and function in DNA sensing. Follow-up experiments demonstrated that IFIX binds viral DNA, suppresses HSV-1 replication, and induces interferon expression [12]. Probing the IFIX interactome even further during HSV-1 infection revealed associations with several components of the five friends of methylated chromatin target of Prmt1 (5FMC) complex [33], which functions in epigenetic regulation [68] and was later found to also interact specifically with oligomerized IFI16 [29].

Several important discoveries of cGAS function have been made using AP-MS, and we must also emphasize that the discovery of cGAS as a DNA sensor was initially enabled by the MS characterization of the cellular proteome. Stimulation of STING by cGAMP was discovered in 2013 [69], but the source of the cyclic GMP-AMP synthase activity remained unclear. Thus, cGAS was identified by integrating shotgun proteomics and cellular fractionation in order to pinpoint the protein whose expression pattern matched that of cGAS activity [13]. Since then, targeted IP-MS studies focused on specific interactions of interest uncovered cGAS associations with several cellular proteins that support immune function, including TRIM56 [70], PARP1 [16], and IFI16 [14], among many others 
(Figure 3). The interaction between cGAS and IFI16 is particularly interesting because it touches on the question of redundancy for these proteins in the nuclear DNA sensing pathway. It was determined that, during HSV-1 infection, nuclear cGAS interacts with IFI16 for the purpose of stabilizing IFI16 in order to promote immune signaling [14,71]. The knowledge of cGAS interactions was later expanded with an IP-MS study of its interactome, which was further integrated with quantitative profiling of cellular proteome alterations during HSV-1 infection [51]. This interactome revealed the cGAS interaction with the RNA sensor OASL, which was demonstrated to repress cGAS activity as a host negative feedback loop for regulating cytokine induction [51].

Currently, the only study to have utilized AP-MS to study hnRNPA2B1 in the context of DNA sensing is the one in which it was discovered [17]. As indicated above, here, biotinylated HSV-1 genomes were isolated early during infection and the interacting proteins were identified via MS. These data were then cross-referenced with shotgun MS of nuclear/cytoplasmic fractionated cells in order to identify proteins that undergo nucleocytoplasmic translocation during infection. This approach enabled the authors to identify proteins that both bind viral DNA and shuttle to the cytoplasm, potentially for the purpose of activating STING-TBK1-IRF3. IP-MS was then utilized to gain a mechanistic understanding of interferon induction by hnRNPA2B1, showing that it does indeed interact with STING and TBK1 following HSV-1 infection.

The discovery of interactions with nuclear DNA sensors has also led to the characterization of mechanisms by which viruses evade cellular innate immunity. For example, recognizing the ability of the HCMV tegument protein pUL83 to inhibit the nuclear oligomerization of the pyrin domains of IFI16 and IFIX (Figure 3) derived from the identification of their interactions from an IP-MS study [26]. In agreement with its reported ability to target IFI16 for degradation during HSV-1 infection [28], the ICP0 interaction with IFI16 was demonstrated by IP-MS [50]. IP studies followed by targeted assays were valuable for identifying other mechanisms of virus immune evasion, such as the inhibition of cGAMP production by the KSHV virion protein ORF52 [72] and the HSV-1 tegument protein pUL37 (detailed in the PTM section below) [39] (Figure 3).

\subsection{Post-Translational Modifications for Finely Tuning DNA Sensor Function}

Beyond interactions with other biomolecules, the ability of DNA sensors to detect and respond to pathogenic invasion is closely tied to their regulation by PTMs. Changes to protein structure via phosphorylation, acetylation, ubiquitination, and SUMOylation, among others, enable the rapid regulation of protein function, and the addition or removal of PTMs is a tightly regulated cellular process in response to stress. MS has been well-established as the main method for accurate and unbiased detection of site-specific PTMs in different cellular contexts and has also contributed to the discovery of a multitude of DNA sensor PTMs (Table 2).

Broadly speaking, PTMs are inherent to the ability of a cell to induce immune signaling cascades in response to pathogen infection. The necessity of PTMs for immune signaling is exemplified by the activation of IFN $\beta$ expression that hinges upon phosphorylation of both TBK1 and IRF3 in STING-dependent signaling [1]. Further, PTMs of DNA sensors have been shown to directly contribute to immune activation. The hnRNPA2B1 interactome also revealed an interaction with the nuclear protein JMJD6, which facilitates demethylation of hnRNPA2B1 at Arg226. This alteration in hnRNPA2B1 structure is necessary for its dimerization, nucleocytoplasmic translocation, and subsequent interferon induction [17]. Thus, the necessity of Arg226 demethylation for hnRNPA2B1 DNA sensing highlights the importance of protein modification in this immune response. 
Table 2. Known post-translational modifications of nuclear DNA sensors.

\begin{tabular}{|c|c|c|c|}
\hline DNA Sensor & Modification & Residues & Reference in Which First Identified \\
\hline \multirow{6}{*}{ IFI16 } & Acetylation & K45, K99, K128, K214, K444, K451, K505, K542, K558 & [10] \\
\hline & \multirow{2}{*}{ Phosphorylation } & S95, S106, S153, S168, S174, S724 & [10] \\
\hline & & S575 & [73] \\
\hline & \multirow{3}{*}{ SUMOylation } & K116, K561 & [74] \\
\hline & & K128 & [75] \\
\hline & & K683 & [76] \\
\hline \multirow{11}{*}{ cGAS } & \multirow{2}{*}{ Acetylation } & K7, K50, K384, K392, K394, K414 & [52] \\
\hline & & K198, K285, K292, K355, K432, K479 & [53] \\
\hline & Deamidation & $\begin{array}{c}\text { N196, N377, Q436, Q439 in mice (N210, N389, Q451, } \\
\text { Q454 in human) }\end{array}$ & [39] \\
\hline & Glutamylation & E272 (poly), E302 (mono) & [77] \\
\hline & \multirow{4}{*}{ Phosphorylation } & S37, S116, S201, S221, S263 & [53] \\
\hline & & S143 & [73] \\
\hline & & $\mathrm{Y} 215$ & [16] \\
\hline & & S305 & [78] \\
\hline & SUMOylation & K217 and K464 in mice (K231 and K479 in human) & [79] \\
\hline & \multirow{2}{*}{ Ubiquitination } & K271 and K464 (poly) in mice & [79] \\
\hline & & K335 (mono) & [70] \\
\hline \multirow{11}{*}{ hnRNPA2B1 } & \multirow{2}{*}{ Acetylation } & M1 & [80] \\
\hline & & K168, K173 & [81] \\
\hline & Demethylation & $\mathrm{R} 226$ & [17] \\
\hline & Methylation & R203, R213, R228, R238, R266, R325, R350 & [82] \\
\hline & \multirow{5}{*}{ Phosphorylation } & $\begin{array}{c}\text { T4, S29, T140, T159, T176, S189, S201, S212, S225, } \\
\text { S259, S324, Y331, S341, S344 }\end{array}$ & [83] \\
\hline & & S85, S212, S259, S344 & [84] \\
\hline & & S149, S231 & [73] \\
\hline & & $\mathrm{S} 236$ & [85] \\
\hline & & S347 & [86] \\
\hline & \multirow{2}{*}{ SUMOylation } & K22, K104, K112, K120, K137, K152, K168, K173 & [75] \\
\hline & & K120, K186 & [74] \\
\hline
\end{tabular}


The initial discovery of IFI16 as a viral DNA sensor pointed to its ability to recognize pathogenic DNA in the cytoplasm, and further characterization of this sensor also solidified its nuclear DNA sensing function. However, the mechanisms regulating IFI16 subcellular localization remained unknown. Furthermore, its relative nuclear or cytoplasmic distribution was shown to be cell type dependent, with its localization being predominantly nuclear in lymphoid, epithelial, endothelial, and fibroblast cells, tissues that tend to be among the first infected by an invading virus. In 2012, our group reported that IFI16 contains a bipartite nuclear localization signal (NLS) and, using MS, identified several acetylation sites within the NLS [10]. IFI16 mutation experiments indicated that NLS acetylation at Lys99 and Lys128 inhibits nuclear import and abrogates IFI16 DNA sensing during HSV-1 infection. This discovery was critical for supporting that IFI16 predominantly senses viral DNA within the nucleus during herpesvirus infection. A number of studies have since demonstrated that IFI16 is regulated by different types of PTMs during viral infections, which additionally include phosphorylation and SUMOylation (Table 2) [10,73-76]. PTM-driven mechanisms also underly the ability of the cell to activate DNA sensors by modifying viral immune evasion proteins, thereby crippling their functions. For example, eight phosphorylation sites were discovered on the HCMV tegument protein pUL83 and mutational analyses demonstrated that its binding to the IFI16 PYD can be compromised by Ser364 phosphorylation within the pUL83 pyrin association domain [26].

PTMs of cGAS during DNA sensing have also started to be recognized for their importance in cGAS regulation and function, and MS-based PTM analysis has been crucial for identifying key regulatory hubs. For example, Zhang et al. found that the HSV-1 tegument protein pUL37 antagonizes cGAS during infection [39]. This protein is a known deamidase that acts on the dsRNA sensing protein RIG-I [87] to prevent immune signaling during HSV-1 infection; thus, the authors proposed a similar deamidation event would prevent cGAS signaling. Using tandem MS, they discovered several deamidation sites within the Mab21 enzyme domain and further identified that deamidation of Asn210 indeed impairs the ability of cGAS to produce cGAMP upon binding to dsDNA [39].

Several other important cGAS PTMs have been identified in recent years that function to either suppress or activate cGAS activity during DNA sensing. These PTMs include phosphorylation, glutamylation, ubiquitination, and SUMOylation (Table 2). An IP-MS study of cGAS followed by mutational analysis of the identified modified sites led to the finding that the kinase Akt phosphorylates cGAS Ser305, suppressing cGAMP production and interferon expression [78]. Additionally, glutamylation of cGAS at two distinct sites have been shown to impede cGAS activity [77]. After identifying that the cytosolic carboxypeptidases 5 and 6 (CCP5 and CCP6) contribute to activation of IRF3 during infection with DNA viruses HSV-1 and VACV, Xia et al. used MS to identify cGAS as a substrate of these protein. As CCP5 and CCP6 reverse glutamylation, this then led to the discovery that cGAS activity is suppressed through Glu302 monoglutamylation by tubulin tyrosine ligase-like protein 4 (TTLL4), which prevents cGAMP production, and through Glu272 polyglutamylation by TTLL6, which weakens the cGAS DNA binding ability [77]. More recently, MS analyses led to the discovery that cGAS is also acetylated at several lysine residues, with acetylation at Lys384, Lys394, and Lys414 suppressing cGAS-mediated cGAMP production [52] and apoptosis [53], and Lys198 acetylation promoting cGAS-induced antiviral cytokine expression [53]. Targeted MS/MS quantification of site-specific acetylation during infection demonstrated that the level of Lys198 acetylation decreased during HSV-1 and HCMV infections [53], pointing to the possible presence of a viral immune evasion strategy targeting this residue to control host immune response.

Targeted studies that do not utilize MS have also identified important cGAS PTMs (Table 2). Mutational analysis of cGAS revealed that phosphorylation at Tyr215 inhibits cGAS nuclear translocation upon DNA damage, and a tyrosine kinase knockdown screen showed that B-lymphoid tyrosine kinase controls phosphorylation at this residue [16]. As another example, SUMOylation of murine cGAS by TRIM38 enhanced cGAS DNA sensing by preventing polyubiquitination and subsequent degradation of cGAS [79]. Further investigations of the aforementioned interaction between cGAS and TRIM56 
revealed that TRIM56 acts to monoubiquitinate cGAS in order to promote its dimerization and facilitate cytosolic DNA sensing [70].

\section{Defining the Cellular Landscape Representative of Immune Activation}

In addition to providing specific information regarding the regulation of nuclear DNA sensors, omic studies have also informed of the global alterations occurring in host cells during immune activation. Infections with DNA viruses result in major changes in mRNA expression, protein abundances, interaction networks and PTMs, cellular metabolism, and secretion. During infection, the virus seeks to inhibit host defenses, co-opt cellular machinery, and rewire the cellular metabolome to facilitate production of progeny virions. Meanwhile, the host attempts to reduce energy expenditure while producing and secreting antiviral cytokines that will slow the spread of infection. Transcriptome, proteome, metabolome, and secretome studies have been critical for gaining an understanding of these broad cellular alterations occurring during the progression of virus infections. Temporal transcriptomic and proteomic investigations have been carried out to determine whether a regulation occurs through changes at the transcript or protein level during infection and to correlate expression trends with phenotypes.

Given that viruses appropriate the host cell transcription machinery and RNA processing, a range of transcriptome studies have been performed to monitor temporal cellular and viral transcript levels during different types of infections. For example, DNA microarrays have been used extensively to study the effect infection on transcription by HSV-1 [88,89], HCMV [56,90-93], KSHV [94,95], and the porcine alphaherpesvirus pseudorabies virus $[96,97]$, among others. Similar to proteomic technologies, improvements in sequencing methods have greatly impacted our understanding of host cell response to viral infection. The emergence of RNA sequencing (RNA-seq) as an unbiased method that is both more sensitive and precise than microarrays [98] has benefitted the fields of virology and immunology by more broadly capturing the cellular and viral transcriptional landscape during infection, including the expression of interferon-stimulated genes (ISGs). This technique was used to demonstrate that HSV-1 infection of skin fibroblasts led to the upregulation of 596 genes, downregulation of only 61 genes, and 1032 alternative splicing events [99]. RNA-seq analysis of HCMV infection in human fibroblasts showed that genes involved in the epithelial-to-mesenchymal transition (EMT) are downregulated, while genes that support mesenchymal-to-epithelial transition (MET) are induced, suggesting HCMV prefers an epithelial cellular state for replication [100]. Furthermore, RNA-seq has recently been used to explore transcriptomic differences between endemic Kaposi's sarcoma (EnKS) and epidemic Kaposi's sarcoma (EpKS), which results from KSHV and HIV-1 co-infection in sub-Saharan Africa [101]. This study found that a subset of genes involved in tumorigenesis and immune responses displayed increased dysregulation in EnKS lesions, but the overall gene expression profiles between EnKS and EpKS correlated strongly.

Investigation of cellular transcriptomes through RNA-seq have also revealed important aspects of nuclear DNA sensor regulation outside of the context of virus infection. To provide a few examples, expression of IFI16, among several other innate immunity proteins, was upregulated in macrophages infected with the bacterium Campylobacter concisus [102]; tumor-bearing mice with deletion of the IFI16 homolog p204, when compared to WT mice, lacked the ability to induce the upregulation of 382 genes, indicating the extensive involvement of IFI16 in antitumor immunity [57]; and RNA-seq studies of an alcohol-related liver disease model in mice revealed that liver damage from excessive alcohol consumption is mediated by cGAS activation of the STING-TBK1-IRF3 pathway [103].

Similar to transcriptome studies, whole-cell proteome investigations with mass spectrometry have led to a wealth of information about both viral and cellular protein abundances during virus infection, uncovering changes linked to innate immune responses and virus immune evasion strategies. Given the finely tuned temporal regulation of virus replication steps, assessments of the cellular proteomes have been carried out at multiple time points as the infection progresses, as reported for infection with HSV-1 [51,104], HCMV [105,106], and KSHV [107,108]. In conjunction with temporal studies, infection 
with virus strains that lack the ability to inhibit DNA sensors offered a view of proteome changes during an active host immune response. For example, the $d 106 \mathrm{HSV}-1$ strain contains mutations in four of five immediate-early proteins (ICP4, ICP22, ICP27, and ICP47) but expresses functional ICP0 [109]. Infection with this virus results in increased induction of cytokines and apoptosis when compared to infection with WT HSV-1 [50,110]. By comparing temporal proteome changes during WT and 1106 HSV-1 infections, we discovered the upregulation of several proteins involved in innate immunity and apoptosis, and integration with cGAS IP-MS led to the discovery of OASL-mediated cGAS inhibition [51]. Additional MS studies have been carried out to characterize proteome changes during HSV-1 infection in a range of cell types and to compare alterations induced by different virus strains [51,54,104,111-121]. Spatial proteomics [122] has further provided the ability to characterize changes in proteome organization during infection [123], as well as discover viral proteins that localize to distinct organelles to regulate their functions, as shown for HCMV infection [124]. Recent years have also seen the increased integration of proteome studies with global PTM studies, where the infection-induced host phosphorylation, acetylation, SUMOylation, ubiquitination landscapes, to name just a few, have been started to be characterized [125-128]. Knowledge of global PTM changes have furthered the understanding of signaling cascades during infection and have helped to identify regulatory hubs at the interface between host defense and virus production. Another proteomic perspective of regulatory hubs is provided by the identification of functional protein complexes that are activated or inhibited during an infection process. The use of thermal co-aggregation profiling MS was recently demonstrated to offer a global view of temporal assembly and disassembly of host-host, host-viral, and viral-viral protein interaction events during HCMV infection, including the regulation of complexes involved in host immunity [106]. Altogether, these MS-based proteomic investigations of whole-cell and subcellular proteomes, interactomes, and PTMs provide rich information regarding host cell changes in response to viral infections. The integration of these different datasets promises to reveal a systems-view of the host environment during infection, which can aid in the formulation of specific biological hypotheses, the identification of changes linked to viral pathologies, and the discovery of therapeutic targets. Therefore, efforts have been and continue to be placed in the development of computational platforms that facilitate data integration in a user-friendly manner [129-135]. One platform specifically applied to studying viral infections is the Interaction Visualization in Space and Time Analysis (Inter-ViSTA), a web-accessible platform that enables integration of interactome, proteome, and functional traits to build animated temporal interaction networks [136]. For example, this analysis platform readily illustrated dynamic localization-dependent interactions of the HCMV protein pUL37 that function to either inhibit immune responses early in infection or promote peroxisome metabolic functions that benefit virus assembly late in infection.

Metabolome profiling brings another powerful omic tool to understanding the biology of virus infection and host defense mechanisms. Replication and assembly of virions is an energy-intensive process that requires the virus to trigger the cellular machinery to increase protein and lipid production for building progeny virions, as shown for numerous viruses [137]. Great effort has been put into understanding the mechanisms underlying metabolic reprogramming during a number of viral infections, including with HCMV and HSV-1 [55,138]. Integrating MS-based metabolomics with molecular virology techniques has proved valuable towards this goal; for example, a recent study of HCMV infection found that the viral protein pUL37 is critical for remodeling cellular metabolism by increasing production of very-long-chain fatty acids [139]. Given that pUL37 is an important immune evasion protein, such as by inhibiting cGAS function [39], it is likely that pUL37 bridges proviral metabolism with innate immune regulation during HCMV infection. Future studies geared towards elucidating the relationships between these fundamental infection processes promise to reveal key players in virus replication and spread.

Finally, the secretion of proteins into the extracellular space is crucial for communication with adjacent cells and is the foundation of innate immunity. Interferons secreted by infected cells bind to receptors on neighboring cells to induce immunomodulatory and antiproliferative effects, 
a phenomenon that has been known for several decades [140]. Upon binding to the interferon receptor and activating the JAK-STAT signaling pathway, dozens of transcripts are upregulated, including additional cytokines [141], altogether leading to inflammatory response and impacting disease pathology. Therefore, examining the secretome of infected cells is a necessary component for understanding these complex intercellular communications [142]. MS-based studies have leveraged proteomics and lipidomics methods to define the composition of secreted biomolecular complexes during infection, including extracellular vesicles known as exosomes [143]. For example, quantitative proteomic analysis of exosomes from HSV-1-infected macrophages demonstrated that specific subsets of cytokines, inflammatory proteins, and transcription factors are secreted rapidly upon infection, thus priming immune response in neighboring cells [144]. Virus-driven secretomes can also impact cellular and tissue physiology, as demonstrated by two recent studies that examined how molecules secreted by herpesvirus infected cells determine local immune and growth responses in neutrophils [145] and cortical brain cells [54], respectively.

\section{The Missing Link: Genomics for Understanding the Viral DNA-DNA Sensor Interface}

AP-MS isolations of viral DNA during infection have been fundamental for the discovery of nuclear DNA sensors. However, the regulation and complete outcome of the interactions between DNA sensors and viral DNA remain to be fully characterized. In this section, we discuss the conundrum of how DNA sensors bind to pathogenic DNA in a sequence-independent manner, while also being shown to specifically function in repression of viral gene expression.

Though nuclear DNA sensors avoid autoreactivity with host DNA, they do not appear to recognize any specific virus nucleotide sequence motifs or DNA modifications. In fact, for a protein to be classified as a DNA sensor, one requirement is that it should bind to DNA in a sequence-independent manner, thereby having the capacity to recognize multiple DNA pathogens. For example, for the HIN-200 domains of IFI16 and IFIX, their sequence-independent binding to dsDNA is accomplished via weak electrostatic interactions between positively charged amino acids and the negatively charged DNA phosphate backbone $[25,146,147]$. It was also demonstrated that IFI16 preferentially binds to specific DNA forms, namely cruciform structures, superhelical, and quadruplex DNA, which could maximize contact between the phosphate backbone and the basic amino acids in the HIN-200 oligonucleotide/oligosaccharide binding folds $[148,149]$. However, there remains no evidence of DNA sequence preference, and it is hypothesized that the activation of immune responses by IFI16 relies on cooperative assembly of IFI16 oligomers, which is limited on host DNA by tight chromatin packing $[29,150]$. Examinations of crystal structures of cGAS with a dsDNA ligand have similarly shown that the cGAS Mab21 domain binds to the phosphate backbone of B-form DNA without any sequence specificity [151-154]. In contrast with IFI16, it is proposed that cGAS-mediated autoreactivity is inhibited by tight tethering of cGAS to host chromatin through a salt-resistant interaction that is independent of the domains required for cGAS activation [34,35].

Such in vitro experiments indicate that DNA binding is sequence independent, but the propensity of DNA sensors to interact with transcriptional regulatory proteins that are sequence specific (e.g., the HSV-1 transcriptional activator ICP4 [155]) could induce preferential accumulation at certain DNA loci. Furthermore, given that IFI16 and IFIX have also been shown to function in host antiviral response by repressing virus transcription [29-33], how does DNA sensor binding affect the chromatin structure at specific binding sites? Are other protein-DNA interactions increased or decreased at these loci, and how does this affect viral transcription and replication?

After entering the nucleus, herpesvirus genomes are subjected to chromatinization by host cell histones [156], and it has been demonstrated that IFI16 promotes the addition of the repressive heterochromatin mark H3K9me3 on viral DNA $[31,32,157]$. Thus far, these studies investigating where IFI16 and H3K9me3 interact with viral genomes have been conducted using chromatin immunoaffinity purification (ChIP) coupled with PCR or RT-qPCR [31,32,157]. Herpesviruses have large genomes (e.g., HSV-1 is $\sim 152$ kilobase pairs and contains $\sim 80$ genes), yet this approach is limited by only 
examining protein-DNA interactions at a few viral genes. Higher throughput techniques can help to more broadly represent interactions between viral DNA and DNA sensors and the subsequent effects on the viral genome chromatin landscape.

To assess where DNA sensors bind to the viral genome, ChIP sequencing (ChIP-seq) is an appropriate technique that has previously been used to study how the HSV-1 genome interacts with ICP4 [155], RNA polymerase II [158], and the transcription factor CCCTC-binding factor (CTCF) [159]. Applying this technique with nuclear DNA sensors would help determine whether DNA sensing is fully a sequence-independent process or whether additional factors within the cell can also cause accumulation of the DNA sensor at specific DNA loci.

Histone PTMs such as H3K9me3 are often used as proxies for determining whether a DNA locus resides in a euchromatin or heterochromatin region of DNA [160]. To investigate how DNA sensors affect the chromatinization of viral genomes, knockout studies can be followed by H3, H3K4me3, and $\mathrm{H} 3 \mathrm{~K} 9 \mathrm{me} 3 \mathrm{ChIP}-$ seq. However, these modifications only act as a proxy for the chromatin structure and are not a direct readout of chromatin structure. Additionally, the cost of such experiments must also be considered, as the requirement for multiple conditions per sample considerably increases the amount of sequencing required. Measuring chromatin accessibility is often a better way to examine chromatin structure and can be probed through techniques such as MNase-seq [161], DNase-seq [162], FAIRE-seq [163], and ATAC-seq [164]. Furthermore, integration of protein-DNA interaction mapping data with chromatin accessibility data following DNA sensor knockout can help to identify how DNA sensor binding both globally and locally affects viral DNA structure. Thus, high-throughput sequencing techniques that explore epigenomic changes will be pivotal to continuing to expand our understanding of nuclear DNA sensor mechanisms.

\section{Concluding Remarks}

The development of omics techniques has helped to greatly expedite biological research. The topic discussed in this paper, the elegantly complex process of nuclear DNA sensing during virus infection has benefited immensely from the ability to examine the identities and PTM states of all proteins within the host cell. The general idea behind DNA sensors is rather simple: bind pathogenic DNA and initiate antiviral signaling pathways. However, the mechanisms by which the nuclear DNA sensors IFI16, IFIX, cGAS, and hnRNPA2B1 activate large-scale transcriptome, proteome, and secretome changes rely on the precise coordination of a multitude protein interactions and PTMs. Here, we have discussed how omics techniques, particularly those implementing mass spectrometry, have led to the discovery and characterization of these nuclear DNA sensors. The future expansion of these investigations to integrative multiomics studies that include epigenomic assays promise to substantially contribute to a more in-depth understanding of the intricacies of DNA sensing, its dysregulation, and connected pathologies.

Author Contributions: Conceptualization, T.R.H. and I.M.C.; writing-original draft preparation, T.R.H. and I.M.C.; writing-review and editing, T.R.H. and I.M.C. All authors have read and agreed to the published version of the manuscript.

Funding: We are grateful for funding from the NIH (R01 GM114141) and Mallinckrodt Scholar Award to IMC, and from the NIH training grant from NIGMS (T32GM007388).

Conflicts of Interest: The authors declare no conflict of interest.

\section{References}

1. McNab, F.; Mayer-Barber, K.; Sher, A.; Wack, A.; O'Garra, A. Type I interferons in infectious disease. Nat. Rev. Immunol. 2015, 15, 87-103. [CrossRef]

2. Paludan, S.R.; Bowie, A.G. Immune Sensing of DNA. Immunity 2013, 38, 870-880. [CrossRef] [PubMed]

3. Wertheim, J.O.; Smith, M.D.; Smith, D.M.; Scheffler, K.; Kosakovsky Pond, S.L. Evolutionary origins of human herpes simplex viruses 1 and 2. Mol. Biol. Evol. 2014, 31, 2356-2364. [CrossRef] [PubMed] 
4. Renner, D.W.; Szpara, M.L. Impacts of Genome-Wide Analyses on Our Understanding of Human Herpesvirus Diversity and Evolution. J. Virol. 2017, 92, 92. [CrossRef] [PubMed]

5. Cagliani, R.; Forni, D.; Mozzi, A.; Sironi, M. Evolution and genetic diversity of primate cytomegaloviruses. Microorganisms 2020, 8, 624. [CrossRef] [PubMed]

6. Hurst, T.P.; Aswad, A.; Karamitros, T.; Katzourakis, A.; Smith, A.L.; Magiorkinis, G. Interferon-inducible protein 16 (IFI16) has a broad-spectrum binding ability against ss DNA targets: An evolutionary hypothesis for antiretroviral checkpoint. Front. Microbiol. 2019, 10, 1426. [CrossRef] [PubMed]

7. Unterholzner, L.; Bowie, A.G. Innate DNA sensing moves to the nucleus. Cell Host Microbe 2011, 9, $351-353$. [CrossRef] [PubMed]

8. Diner, B.A.; Lum, K.K.; Cristea, I.M. The Emerging Role of Nuclear Viral DNA Sensors. J. Biol. Chem. 2015, 290, 26412-26421. [CrossRef]

9. Unterholzner, L.; Keating, S.E.; Baran, M.; Horan, K.A.; Jensen, S.B.; Sharma, S.; Sirois, C.M.; Jin, T.; Latz, E.; Xiao, T.S.; et al. IFI16 is an innate immune sensor for intracellular DNA. Nat. Immunol. 2010, 11,997-1004. [CrossRef]

10. Li, T.; Diner, B.A.; Chen, J.; Cristea, I.M. Acetylation modulates cellular distribution and DNA sensing ability of interferon-inducible protein IFI16. Proc. Natl. Acad. Sci. USA 2012, 109, 10558-10563. [CrossRef]

11. Kerur, N.; Veettil, M.V.; Sharma-Walia, N.; Bottero, V.; Sadagopan, S.; Otageri, P.; Chandran, B. IFI16 Acts as a Nuclear Pathogen Sensor to Induce the Inflammasome in Response to Kaposi Sarcoma-Associated Herpesvirus Infection. Cell Host Microbe 2011, 9, 363-375. [CrossRef] [PubMed]

12. Diner, B.A.; Li, T.; Greco, T.M.; Crow, M.S.; Fuesler, J.A.; Wang, J.; Cristea, I.M. The functional interactome of PYHIN immune regulators reveals IFIX is a sensor of viral DNA. Mol. Syst. Biol. 2015, 11, 787. [CrossRef] [PubMed]

13. Sun, L.; Wu, J.; Du, F.; Chen, X.; Chen, Z.J. Cyclic GMP-AMP synthase is a cytosolic DNA sensor that activates the type I interferon pathway. Science 2013, 339, 786-791. [CrossRef] [PubMed]

14. Orzalli, M.H.; Broekema, N.M.; Diner, B.A.; Hancks, D.C.; Elde, N.C.; Cristea, I.M.; Knipe, D.M. cGAS-mediated stabilization of IFI16 promotes innate signaling during herpes simplex virus infection. Proc. Natl. Acad. Sci. USA 2015, 112, E1773-E1781. [CrossRef] [PubMed]

15. Diner, B.A.; Lum, K.K.; Toettcher, J.E.; Cristea, I.M. Viral DNA Sensors IFI16 and Cyclic GMP-AMP Synthase Possess Distinct Functions in Regulating Viral Gene Expression, Immune Defenses, and Apoptotic Responses during Herpesvirus Infection. MBio 2016, 7, e01553-16. [CrossRef]

16. Liu, H.; Zhang, H.; Wu, X.; Ma, D.; Wu, J.; Wang, L.; Jiang, Y.; Fei, Y.; Zhu, C.; Tan, R.; et al. Nuclear cGAS suppresses DNA repair and promotes tumorigenesis. Nature 2018, 563, 131-136. [CrossRef]

17. Wang, L.; Wen, M.; Cao, X. Nuclear hnRNPA2B1 initiates and amplifies the innate immune response to DNA viruses. Science 2019, 365, eaav0758. [CrossRef]

18. Burleigh, K.; Maltbaek, J.H.; Cambier, S.; Green, R.; Gale, M.; James, R.C.; Stetson, D.B. Human DNA-PK activates a STING-independent DNA sensing pathway. Sci. Immunol. 2020, 5, eaba4219. [CrossRef]

19. Sato, M.; Tanaka, N.; Hata, N.; Oda, E.; Taniguchi, T. Involvement of the IRF family transcription factor IRF-3 in virus-induced activation of the IFN-beta gene. FEBS Lett. 1998, 425, 112-116. [CrossRef]

20. Lin, R.; Heylbroeck, C.; Pitha, P.M.; Hiscott, J. Virus-dependent phosphorylation of the IRF-3 transcription factor regulates nuclear translocation, transactivation potential, and proteasome-mediated degradation. Mol. Cell. Biol. 1998, 18, 2986-2996. [CrossRef]

21. Ishikawa, H.; Ma, Z.; Barber, G.N. STING regulates intracellular DNA-mediated, type I interferon-dependent innate immunity. Nature 2009, 461, 788-792. [CrossRef] [PubMed]

22. Tanaka, Y.; Chen, Z.J. STING specifies IRF3 phosphorylation by TBK1 in the cytosolic DNA signaling pathway. Sci. Signal. 2012, 5, ra20. [CrossRef] [PubMed]

23. Bertin, J.; DiStefano, P.S. The PYRIN domain: A novel motif found in apoptosis and inflammation proteins. Cell Death Differ. 2000, 7, 1273-1274. [CrossRef] [PubMed]

24. Albrecht, M.; Choubey, D.; Lengauer, T. The HIN domain of IFI-200 proteins consists of two OB folds. Biochem. Biophys. Res. Commun. 2005, 327, 679-687. [CrossRef] [PubMed]

25. Jin, T.; Perry, A.; Jiang, J.; Smith, P.; Curry, J.A.; Unterholzner, L.; Jiang, Z.; Horvath, G.; Rathinam, V.A.; Johnstone, R.W.; et al. Structures of the HIN Domain:DNA Complexes Reveal Ligand Binding and Activation Mechanisms of the AIM2 Inflammasome and IFI16 Receptor. Immunity 2012, 36, 561-571. [CrossRef] 
26. Li, T.; Chen, J.; Cristea, I.M.M. Human Cytomegalovirus Tegument Protein pUL83 Inhibits IFI16-Mediated DNA Sensing for Immune Evasion. Cell Host Microbe 2013, 14, 591-599. [CrossRef] [PubMed]

27. Stratmann, S.A.; Morrone, S.R.; van Oijen, A.M.; Sohn, J. The innate immune sensor IFI16 recognizes foreign DNA in the nucleus by scanning along the duplex. Elife 2015, 4, e11721. [CrossRef] [PubMed]

28. Orzalli, M.H.; DeLuca, N.A.; Knipe, D.M. Nuclear IFI16 induction of IRF-3 signaling during herpesviral infection and degradation of IFI16 by the viral ICP0 protein. Proc. Natl. Acad. Sci. USA 2012, 109, E3008-E3017. [CrossRef]

29. Lum, K.K.; Howard, T.R.; Pan, C.; Cristea, I.M. Charge-mediated pyrin oligomerization nucleates antiviral IFI16 sensing of herpesvirus DNA. MBio 2019, 10, 10. [CrossRef]

30. Gariano, G.R.; Dell'Oste, V.; Bronzini, M.; Gatti, D.; Luganini, A.; De Andrea, M.; Gribaudo, G.; Gariglio, M.; Landolfo, $\mathrm{S}$. The intracellular DNA sensor IFI16 gene acts as restriction factor for human cytomegalovirus replication. PLoS Pathog. 2012, 8, e1002498. [CrossRef]

31. Orzalli, M.H.; Conwell, S.E.; Berrios, C.; DeCaprio, J.A.; Knipe, D.M. Nuclear interferon-inducible protein 16 promotes silencing of herpesviral and transfected DNA. Proc. Natl. Acad. Sci. USA 2013, 110, E4492-E4501. [CrossRef] [PubMed]

32. Johnson, K.E.; Bottero, V.; Flaherty, S.; Dutta, S.; Singh, V.V.; Chandran, B. IFI16 Restricts HSV-1 Replication by Accumulating on the HSV-1 Genome, Repressing HSV-1 Gene Expression, and Directly or Indirectly Modulating Histone Modifications. PLoS Pathog. 2014, 10, e1004503. [CrossRef] [PubMed]

33. Crow, M.S.; Cristea, I.M. Human antiviral protein IFIX suppresses viral gene expression during herpes simplex virus 1 (HSV-1) infection and is counteracted by virus-induced proteasomal degradation. Mol. Cell. Proteom. 2017, 16, S200-S214. [CrossRef] [PubMed]

34. Volkman, H.E.; Cambier, S.; Gray, E.E.; Stetson, D.B. Tight nuclear tethering of cGAS is essential for preventing autoreactivity. Elife 2019, 8, 8. [CrossRef] [PubMed]

35. Michalski, S.; de Oliveira Mann, C.C.; Stafford, C.; Witte, G.; Bartho, J.; Lammens, K.; Hornung, V.; Hopfner, K.P. Structural basis for sequestration and autoinhibition of cGAS by chromatin. Nature 2020, 1-8. [CrossRef]

36. Munro, T.P.; Magee, R.J.; Kidd, G.J.; Carson, J.H.; Barbarese, E.; Smith, L.M.; Smith, R. Mutational analysis of a heterogeneous nuclear ribonucleoprotein A2 response element for RNA trafficking. J. Biol. Chem. 1999, 274, 34389-34395. [CrossRef]

37. He, Y.; Smith, R. Nuclear functions of heterogeneous nuclear ribonucleoproteins A/B. Cell. Mol. Life Sci. 2009, 66, 1239-1256. [CrossRef]

38. Cuchet-Lourenco, D.; Anderson, G.; Sloan, E.; Orr, A.; Everett, R.D. The Viral Ubiquitin Ligase ICP0 Is neither Sufficient nor Necessary for Degradation of the Cellular DNA Sensor IFI16 during Herpes Simplex Virus 1 Infection. J. Virol. 2013, 87, 13422-13432. [CrossRef]

39. Zhang, J.; Zhao, J.; Xu, S.; Li, J.; He, S.; Zeng, Y.; Xie, L.; Xie, N.; Liu, T.; Lee, K.; et al. Species-Specific Deamidation of cGAS by Herpes Simplex Virus UL37 Protein Facilitates Viral Replication. Cell Host Microbe 2018, 24, 234-248.e5. [CrossRef]

40. Mondini, M.; Vidali, M.; De Andrea, M.; Azzimonti, B.; Airò, P.; D’Ambrosio, R.; Riboldi, P.; Meroni, P.L.; Albano, E.; Shoenfeld, Y.; et al. A novel autoantigen to differentiate limited cutaneous systemic sclerosis from diffuse cutaneous systemic sclerosis: The interferon-inducible gene IFI16. Arthritis Rheum. 2006, 54, 3939-3944. [CrossRef]

41. Mondini, M.; Vidali, M.; Airò, P.; De Andrea, M.; Riboldi, P.; Meroni, P.L.; Gariglio, M.; Landolfo, S. Role of the interferon-inducible gene IFI16 in the etiopathogenesis of systemic autoimmune disorders. Ann. N. Y. Acad. Sci. 2007, 1110, 47-56. [CrossRef] [PubMed]

42. Caneparo, V.; Cena, T.; De Andrea, M.; Dell'Oste, V.; Stratta, P.; Quaglia, M.; Tincani, A.; Andreoli, L.; Ceffa, S.; Taraborelli, M.; et al. Anti-IFI16 antibodies and their relation to disease characteristics in systemic lupus erythematosus. Lupus 2013, 22, 607-613. [CrossRef] [PubMed]

43. Costa, S.; Borgogna, C.; Mondini, M.; De Andrea, M.; Meroni, P.L.; Berti, E.; Gariglio, M.; Landolfo, S. Redistribution of the nuclear protein IFI16 into the cytoplasm of ultraviolet B-exposed keratinocytes as a mechanism of autoantigen processing. Br. J. Dermatol. 2011, 164, 282-290. [CrossRef] [PubMed]

44. Gao, D.; Li, T.; Li, X.D.; Chen, X.; Li, Q.Z.; Wight-Carter, M.; Chen, Z.J. Activation of cyclic GMP-AMP synthase by self-DNA causes autoimmune diseases. Proc. Natl. Acad. Sci. USA 2015, 112, E5699-E5705. [CrossRef] [PubMed] 
45. Gray, E.E.; Treuting, P.M.; Woodward, J.J.; Stetson, D.B. Cutting Edge: cGAS Is Required for Lethal Autoimmune Disease in the Trex1-Deficient Mouse Model of Aicardi-Goutières Syndrome. J. Immunol. 2015, 195, 1939-1943. [CrossRef] [PubMed]

46. Vincent, J.; Adura, C.; Gao, P.; Luz, A.; Lama, L.; Asano, Y.; Okamoto, R.; Imaeda, T.; Aida, J.; Rothamel, K.; et al. Small molecule inhibition of cGAS reduces interferon expression in primary macrophages from autoimmune mice. Nat. Commun. 2017, 8, 750. [CrossRef]

47. Ishii, K.J.; Kawagoe, T.; Koyama, S.; Matsui, K.; Kumar, H.; Kawai, T.; Uematsu, S.; Takeuchi, O.; Takeshita, F.; Coban, C.; et al. TANK-binding kinase-1 delineates innate and adaptive immune responses to DNA vaccines. Nature 2008, 451, 725-729. [CrossRef]

48. Suschak, J.J.; Wang, S.; Fitzgerald, K.A.; Lu, S. Identification of Aim2 as a Sensor for DNA Vaccines. J. Immunol. 2015, 194, 630-636. [CrossRef]

49. Suschak, J.J.; Wang, S.; Fitzgerald, K.A.; Lu, S. A cGAS-Independent STING/IRF7 Pathway Mediates the Immunogenicity of DNA Vaccines. J. Immunol. 2016, 196, 310-316. [CrossRef]

50. Diner, B.A.; Lum, K.K.; Javitt, A.; Cristea, I.M. Interactions of the Antiviral Factor Interferon Gamma-Inducible Protein 16 (IFI16) Mediate Immune Signaling and Herpes Simplex Virus-1 Immunosuppression. Mol. Cell. Proteom. 2015, 14, 2341-2356. [CrossRef]

51. Lum, K.K.; Song, B.; Federspiel, J.D.; Diner, B.A.; Howard, T.; Cristea, I.M. Interactome and Proteome Dynamics Uncover Immune Modulatory Associations of the Pathogen Sensing Factor cGAS. Cell Syst. 2018, 7, 627-642.e6. [CrossRef] [PubMed]

52. Dai, J.; Huang, Y.J.; He, X.; Zhao, M.; Wang, X.; Liu, Z.S.; Xue, W.; Cai, H.; Zhan, X.Y.; Huang, S.Y.; et al. Acetylation Blocks cGAS Activity and Inhibits Self-DNA-Induced Autoimmunity. Cell 2019, 176, 1447-1460.e14. [CrossRef] [PubMed]

53. Song, B.; Greco, T.M.; Lum, K.K.; Taber, C.E.; Cristea, I.M. The DNA Sensor cGAS is Decorated by Acetylation and Phosphorylation Modifications in the Context of Immune Signaling. Mol. Cell. Proteom. 2020, 19, 1193-1208. [CrossRef] [PubMed]

54. Hensel, N.; Raker, V.; Förthmann, B.; Buch, A.; Sodeik, B.; Pich, A.; Claus, P. The Proteome and Secretome of Cortical Brain Cells Infected With Herpes Simplex Virus. Front. Neurol. 2020, 11, 11. [CrossRef] [PubMed]

55. Vastag, L.; Koyuncu, E.; Grady, S.L.; Shenk, T.E.; Rabinowitz, J.D. Divergent effects of human cytomegalovirus and herpes simplex virus-1 on cellular metabolism. PLoS Pathog. 2011, 7, e1002124. [CrossRef]

56. Zhu, H.; Cong, J.P.; Mamtora, G.; Gingeras, T.; Shenk, T. Cellular gene expression altered by human cytomegalovirus: Global monitoring with oligonucleotide arrays. Proc. Natl. Acad. Sci. USA 1998, 95, 14470-14475. [CrossRef]

57. Jian, J.; Wei, W.; Yin, G.; Hettinghouse, A.; Liu, C.; Shi, Y. RNA-Seq analysis of interferon inducible p204-mediated network in anti-tumor immunity. Sci. Rep. 2018, 8, 6495. [CrossRef]

58. Greco, T.M.; Kennedy, M.A.; Cristea, I.M. Proteomic Technologies for Deciphering Local and Global Protein Interactions. Trends Biochem. Sci. 2020, 45, 454-455. [CrossRef]

59. Miteva, Y.V.; Budayeva, H.G.; Cristea, I.M. Proteomics-based methods for discovery, quantification, and validation of protein-protein interactions. Anal. Chem. 2013, 85, 749-768. [CrossRef]

60. Ten Have, S.; Boulon, S.; Ahmad, Y.; Lamond, A.I. Mass spectrometry-based immuno-precipitation proteomics-The user's guide. Proteomics 2011, 11, 1153-1159. [CrossRef]

61. Pichlmair, A.; Reis e Sousa, C. Innate Recognition of Viruses. Immunity 2007, 27, 370-383. [CrossRef] [PubMed]

62. Monroe, K.M.; Yang, Z.; Johnson, J.R.; Geng, X.; Doitsh, G.; Krogan, N.J.; Greene, W.C. IFI16 DNA sensor is required for death of lymphoid CD4 T cells abortively infected with HIV. Science 2014, 343, 428-432. [CrossRef] [PubMed]

63. Dembowski, J.A.; Deluca, N.A. Temporal viral genome-protein interactions define distinct stages of productive herpesviral infection. MBio 2018, 9, 9. [CrossRef] [PubMed]

64. Kim, B.; Arcos, S.; Rothamel, K.; Jian, J.; Rose, K.L.; McDonald, W.H.; Bian, Y.; Reasoner, S.; Barrows, N.J.; Bradrick, S.; et al. Discovery of Widespread Host Protein Interactions with the Pre-replicated Genome of CHIKV Using VIR-CLASP. Mol. Cell 2020, 78, 624-640.e7. [CrossRef] [PubMed]

65. Ouellet Lavallée, G.; Pearson, A. Upstream binding factor inhibits herpes simplex virus replication. Virology 2015, 483, 108-116. [CrossRef]

66. Cabral, J.M.; Oh, H.S.; Knipe, D.M. ATRX promotes maintenance of herpes simplex virus heterochromatin during chromatin stress. Elife 2018, 7. [CrossRef] 
67. Gu, H.; Roizman, B. The Two Functions of Herpes Simplex Virus 1 ICP0, Inhibition of Silencing by the CoREST/REST/HDAC Complex and Degradation of PML, Are Executed in Tandem. J. Virol. 2009, 83, 181-187. [CrossRef]

68. Fanis, P.; Gillemans, N.; Aghajanirefah, A.; Pourfarzad, F.; Demmers, J.; Esteghamat, F.; Vadlamudi, R.K.; Grosveld, F.; Philipsen, S.; Van Dijk, T.B. Five friends of methylated chromatin target of protein-argininemethyltransferase[Prmt]-1 (Chtop), a complex linking arginine methylation to desumoylation. Mol. Cell. Proteom. 2012, 11, 1263-1273. [CrossRef]

69. Wu, J.; Sun, L.; Chen, X.; Du, F.; Shi, H.; Chen, C.; Chen, Z.J. Cyclic GMP-AMP is an endogenous second messenger in innate immune signaling by cytosolic DNA. Science 2013, 339, 826-830. [CrossRef]

70. Seo, G.J.; Kim, C.; Shin, W.J.; Sklan, E.H.; Eoh, H.; Jung, J.U. TRIM56-mediated monoubiquitination of cGAS for cytosolic DNA sensing. Nat. Commun. 2018, 9, 1-13. [CrossRef]

71. Almine, J.F.; O’Hare, C.A.J.; Dunphy, G.; Haga, I.R.; Naik, R.J.; Atrih, A.; Connolly, D.J.; Taylor, J.; Kelsall, I.R.; Bowie, A.G.; et al. IFI16 and cGAS cooperate in the activation of STING during DNA sensing in human keratinocytes. Nat. Commun. 2017, 8, 14392. [CrossRef] [PubMed]

72. Wu, J.J.; Li, W.; Shao, Y.; Avey, D.; Fu, B.; Gillen, J.; Hand, T.; Ma, S.; Liu, X.; Miley, W.; et al. Inhibition of cGAS DNA Sensing by a Herpesvirus Virion Protein. Cell Host Microbe 2015, 18, 333-344. [CrossRef] [PubMed]

73. Olsen, J.V.; Vermeulen, M.; Santamaria, A.; Kumar, C.; Miller, M.L.; Jensen, L.J.; Gnad, F.; Cox, J.; Jensen, T.S.; Nigg, E.A.; et al. Quantitative phosphoproteomics revealswidespread full phosphorylation site occupancy during mitosis. Sci. Signal. 2010, 3, ra3. [CrossRef]

74. Hendriks, I.A.; D’Souza, R.C.J.; Yang, B.; Verlaan-De Vries, M.; Mann, M.; Vertegaal, A.C.O. Uncovering global SUMOylation signaling networks in a site-specific manner. Nat. Struct. Mol. Biol. 2014, 21, 927-936. [CrossRef] [PubMed]

75. Hendriks, I.A.; Lyon, D.; Young, C.; Jensen, L.J.; Vertegaal, A.C.O.; Nielsen, M.L. Site-specific mapping of the human SUMO proteome reveals co-modification with phosphorylation. Nat. Struct. Mol. Biol. 2017, 24, 325-336. [CrossRef]

76. Hendriks, I.A.; Treffers, L.W.; Verlaan-deVries, M.; Olsen, J.V.; Vertegaal, A.C.O. SUMO-2 Orchestrates Chromatin Modifiers in Response to DNA Damage. Cell Rep. 2015, 10, 1778-1791. [CrossRef]

77. Xia, P.; Ye, B.; Wang, S.; Zhu, X.; Du, Y.; Xiong, Z.; Tian, Y.; Fan, Z. Glutamylation of the DNA sensor cGAS regulates its binding and synthase activity in antiviral immunity. Nat. Immunol. 2016, 17, 369-378. [CrossRef]

78. Seo, G.J.; Yang, A.; Tan, B.; Kim, S.; Liang, Q.; Choi, Y.; Yuan, W.; Feng, P.; Park, H.S.; Jung, J.U. Akt Kinase-Mediated Checkpoint of cGAS DNA Sensing Pathway. Cell Rep. 2015, 13, 440-449. [CrossRef]

79. Hu, M.M.; Yang, Q.; Xie, X.Q.; Liao, C.Y.; Lin, H.; Liu, T.T.; Yin, L.; Shu, H.B. Sumoylation Promotes the Stability of the DNA Sensor cGAS and the Adaptor STING to Regulate the Kinetics of Response to DNA Virus. Immunity 2016, 45, 555-569. [CrossRef]

80. Van Damme, P.; Lasa, M.; Polevoda, B.; Gazquez, C.; Elosegui-Artola, A.; Kim, D.S.; De Juan-Pardo, E.; Demeyer, K.; Hole, K.; Larrea, E.; et al. N-terminal acetylome analyses and functional insights of the N-terminal acetyltransferase NatB. Proc. Natl. Acad. Sci. USA 2012, 109, 12449-12454. [CrossRef]

81. Choudhary, C.; Kumar, C.; Gnad, F.; Nielsen, M.L.; Rehman, M.; Walther, T.C.; Olsen, J.V.; Mann, M. Lysine acetylation targets protein complexes and co-regulates major cellular functions. Science 2009, 325, 834-840. [CrossRef] [PubMed]

82. Guo, A.; Gu, H.; Zhou, J.; Mulhern, D.; Wang, Y.; Lee, K.A.; Yang, V.; Aguiar, M.; Kornhauser, J.; Jia, X.; et al. Immunoaffinity enrichment and mass spectrometry analysis of protein methylation. Mol. Cell. Proteomics 2014, 13, 372-387. [CrossRef]

83. Zhou, H.; Di Palma, S.; Preisinger, C.; Peng, M.; Polat, A.N.; Heck, A.J.R.; Mohammed, S. Toward a comprehensive characterization of a human cancer cell phosphoproteome. J. Proteome Res. 2013, 12, 260-271. [CrossRef] [PubMed]

84. Mayya, V.; Lundgren, D.H.; Hwang, S.L.L.; Rezaul, K.; Wu, L.; Eng, J.K.; Rodionov, V.; Han, D.K. Quantitative phosphoproteomic analysis of T Cell receptor signaling reveals system-wide modulation of protein-protein interactions. Sci. Signal. 2009, 2, ra46. [CrossRef] [PubMed]

85. Rigbolt, K.T.G.; Prokhorova, T.A.; Akimov, V.; Henningsen, J.; Johansen, P.T.; Kratchmarova, I.; Kassem, M.; Mann, M.; Olsen, J.V.; Blagoev, B. System-wide temporal characterization of the proteome and phosphoproteome of human embryonic stem cell differentiation. Sci. Signal. 2011, 4, rs3. [CrossRef] [PubMed] 
86. Bian, Y.; Song, C.; Cheng, K.; Dong, M.; Wang, F.; Huang, J.; Sun, D.; Wang, L.; Ye, M.; Zou, H. An enzyme assisted RP-RPLC approach for in-depth analysis of human liver phosphoproteome. J. Proteom. 2014, 96, 253-262. [CrossRef]

87. Zhao, J.; Zeng, Y.; Xu, S.; Chen, J.; Shen, G.; Yu, C.; Knipe, D.; Yuan, W.; Peng, J.; Xu, W.; et al. A Viral Deamidase Targets the Helicase Domain of RIG-I to Block RNA-Induced Activation. Cell Host Microbe 2016, 20, 770-784. [CrossRef]

88. Stingley, S.W.; Ramirez, J.J.G.; Aguilar, S.A.; Simmen, K.; Sandri-Goldin, R.M.; Ghazal, P.; Wagner, E.K. Global Analysis of Herpes Simplex Virus Type 1 Transcription Using an Oligonucleotide-Based DNA Microarray. J. Virol. 2000, 74, 9916-9927. [CrossRef]

89. Aguilar, J.S.; Devi-Rao, G.V.; Rice, M.K.; Sunabe, J.; Ghazal, P.; Wagner, E.K. Quantitative comparison of the HSV-1 and HSV-2 transcriptomes using DNA microarray analysis. Virology 2006, 348, 233-241. [CrossRef]

90. Browne, E.P.; Wing, B.; Coleman, D.; Shenk, T. Altered Cellular mRNA Levels in Human Cytomegalovirus-Infected Fibroblasts: Viral Block to the Accumulation of Antiviral mRNAs. J. Virol. 2001, 75, 12319-12330. [CrossRef]

91. Simmen, K.A.; Singh, J.; Luukkonen, B.G.M.; Lopper, M.; Bittner, A.; Miller, N.E.; Jackson, M.R.; Compton, T.; Früh, K. Global modulation of cellular transcription by human cytomegalovirus is initiated by viral glycoprotein B. Proc. Natl. Acad. Sci. USA 2001, 98, 7140-7145. [CrossRef]

92. Song, Y.J.; Stinski, M.F. Effect of the human cytomegalovirus IE86 protein on expression of E2F-responsive genes: A DNA microarray analysis. Proc. Natl. Acad. Sci. USA 2002, 99, 2836-2841. [CrossRef] [PubMed]

93. Challacombe, J.F.; Rechtsteiner, A.; Gottardo, R.; Rocha, L.M.; Browne, E.P.; Shenk, T.; Altherr, M.R.; Brettin, T.S. Evaluation of the host transcriptional response to human cytomegalovirus infection. Physiol. Genom. 2004, 18, 51-62. [CrossRef] [PubMed]

94. Naranatt, P.P.; Krishnan, H.H.; Svojanovsky, S.R.; Bloomer, C.; Mathur, S.; Chandran, B. Host Gene Induction and Transcriptional Reprogramming in Kaposi's Sarcoma-Associated Herpesvirus (KSHV/HHV-8)-Infected Endothelial, Fibroblast, and B Cells: Insights into Modulation Events Early during Infection. Cancer Res. 2004, 64, 72-84. [CrossRef] [PubMed]

95. Chandriani, S.; Ganem, D. Host transcript accumulation during lytic KSHV infection reveals several classes of host responses. PLoS ONE 2007, 2, e811. [CrossRef]

96. Ray, N.; Enquist, L.W. Transcriptional Response of a Common Permissive Cell Type to Infection by Two Diverse Alphaherpesviruses. J. Virol. 2004, 78, 3489-3501. [CrossRef]

97. Brukman, A.; Enquist, L.W. Suppression of the Interferon-Mediated Innate Immune Response by Pseudorabies Virus. J. Virol. 2006, 80, 6345-6356. [CrossRef]

98. Wang, Z.; Gerstein, M.; Snyder, M. RNA-Seq: A revolutionary tool for transcriptomics. Nat. Rev. Genet. 2009, 10, 57-63. [CrossRef]

99. Hu, B.; Li, X.; Huo, Y.; Yu, Y.; Zhang, Q.; Chen, G.; Zhang, Y.; Fraser, N.W.; Wu, D.; Zhou, J. Cellular responses to HSV-1 infection are linked to specific types of alterations in the host transcriptome. Sci. Rep. 2016, 6, 28075. [CrossRef]

100. Oberstein, A.; Shenk, T. Cellular responses to human cytomegalovirus infection: Induction of a mesenchymal-to-epithelial transition (MET) phenotype. Proc. Natl. Acad. Sci. USA 2017, 114, E8244-E8253. [CrossRef]

101. Lidenge, S.J.; Kossenkov, A.V.; Tso, F.Y.; Wickramasinghe, J.; Privatt, S.R.; Ngalamika, O.; Ngowi, J.R.; Mwaiselage, J.; Lieberman, P.M.; West, J.T.; et al. Comparative transcriptome analysis of endemic and epidemic Kaposi's sarcoma (KS) lesions and the secondary role of HIV-1 in KS pathogenesis. PLoS Pathog. 2020, 16, e1008681. [CrossRef]

102. Kaakoush, N.O.; Deshpande, N.P.; Man, S.M.; Burgos-Portugal, J.A.; Khattak, F.A.; Raftery, M.J.; Wilkins, M.R.; Mitchell, H.M. Transcriptomic and proteomic analyses reveal key innate immune signatures in the host response to the gastrointestinal pathogen Campylobacter concisus. Infect. Immun. 2015, 83, 832-845. [CrossRef] [PubMed]

103. Luther, J.; Khan, S.; Gala, M.K.; Kedrin, D.; Sridharan, G.; Goodman, R.P.; Garber, J.J.; Masia, R.; Diagacomo, E.; Adams, D.; et al. Hepatic gap junctions amplify alcohol liver injury by propagating cGAS-mediated IRF3 activation. Proc. Natl. Acad. Sci. USA 2020, 117, 11667-11673. [CrossRef] [PubMed] 
104. Kulej, K.; Avgousti, D.C.; Sidoli, S.; Herrmann, C.; Della Fera, A.N.; Kim, E.T.; Garcia, B.A.; Weitzman, M.D. Time-resolved global and chromatin proteomics during herpes simplex virus type 1 (HSV-1) infection. Mol. Cell. Proteom. 2017, 16, S92-S107. [CrossRef] [PubMed]

105. Weekes, M.P.; Tomasec, P.; Huttlin, E.L.; Fielding, C.A.; Nusinow, D.; Stanton, R.J.; Wang, E.C.Y.; Aicheler, R.; Murrell, I.; Wilkinson, G.W.G.; et al. Quantitative temporal viromics: An approach to investigate host-pathogen interaction. Cell 2014, 157, 1460-1472. [CrossRef]

106. Hashimoto, Y.; Sheng, X.; Murray-Nerger, L.A.; Cristea, I.M. Temporal dynamics of protein complex formation and dissociation during human cytomegalovirus infection. Nat. Commun. 2020, 11, 1-20. [CrossRef]

107. Hartenian, E.; Gilbertson, S.; Federspiel, J.D.; Cristea, I.M.; Glaunsinger, B.A. RNA decay during gammaherpesvirus infection reduces RNA polymerase II occupancy of host promoters but spares viral promoters. PLoS Pathog. 2020, 16, e1008269. [CrossRef]

108. Gabaev, I.; Williamson, J.C.; Crozier, T.W.M.; Schulz, T.F.; Lehner, P.J. Quantitative Proteomics Analysis of Lytic KSHV Infection in Human Endothelial Cells Reveals Targets of Viral Immune Modulation. Cell Rep. 2020, 33, 33. [CrossRef]

109. Samaniego, L.A.; Neiderhiser, L.; DeLuca, N.A. Persistence and Expression of the Herpes Simplex Virus Genome in the Absence of Immediate-Early Proteins. J. Virol. 1998, 72, 3307-3320. [CrossRef]

110. Sanfilippo, C.M.; Blaho, J.A. ICP0 Gene Expression Is a Herpes Simplex Virus Type 1 Apoptotic Trigger. J. Virol. 2006, 80, 6810-6821. [CrossRef]

111. Rodríguez, M.C.; Dybas, J.M.; Hughes, J.; Weitzman, M.D.; Boutell, C. The HSV-1 ubiquitin ligase ICP0: Modifying the cellular proteome to promote infection. Virus Res. 2020, 285, 198015. [CrossRef]

112. Ouwendijk, W.J.D.; Dekker, L.J.M.; van den Ham, H.-J.; Lenac Rovis, T.; Haefner, E.S.; Jonjic, S.; Haas, J.; Luider, T.M.; Verjans, G.M.G.M. Analysis of Virus and Host Proteomes During Productive HSV-1 and VZV Infection in Human Epithelial Cells. Front. Microbiol. 2020, 11, 1179. [CrossRef] [PubMed]

113. Soh, T.K.; Davies, C.T.R.; Muenzner, J.; Hunter, L.M.; Barrow, H.G.; Connor, V.; Bouton, C.R.; Smith, C.; Emmott, E.; Antrobus, R.; et al. Temporal Proteomic Analysis of Herpes Simplex Virus 1 Infection Reveals Cell-Surface Remodeling via pUL56-Mediated GOPC Degradation. Cell Rep. 2020, 33, 108235. [CrossRef] [PubMed]

114. Antrobus, R.; Grant, K.; Gangadharan, B.; Chittenden, D.; Everett, R.D.; Zitzmann, N.; Boutell, C. Proteomic analysis of cells in the early stages of herpes simplex virus type- 1 infection reveals widespread changes in the host cell proteome. Proteomics 2009, 9, 3913-3927. [CrossRef] [PubMed]

115. Xing, J.; Wang, S.; Li, Y.; Guo, H.; Zhao, L.; Pan, W.; Lin, F.; Zhu, H.; Wang, L.; Li, M.; et al. Characterization of the subcellular localization of herpes simplex virus type 1 proteins in living cells. Med. Microbiol. Immunol. 2011, 200, 61-68. [CrossRef]

116. Bell, C.; Desjardins, M.; Thibault, P.; Radtke, K. Proteomics analysis of Herpes Simplex Virus type 1-infected cells reveals dynamic changes of viral protein expression, ubiquitylation, and phosphorylation. J. Proteome Res. 2013, 12, 1820-1829. [CrossRef]

117. Berard, A.R.; Coombs, K.M.; Severini, A. Quantification of the host response proteome after herpes simplex virus type 1 infection. J. Proteome Res. 2015, 14, 2121-2142. [CrossRef]

118. Drayman, N.; Karin, O.; Mayo, A.; Danon, T.; Shapira, L.; Rafael, D.; Zimmer, A.; Bren, A.; Kobiler, O.; Alon, U. Dynamic Proteomics of Herpes Simplex Virus Infection. MBio 2017, 8, e01612-17. [CrossRef]

119. Cui, Y.H.; Liu, Q.; Xu, Z.Y.; Li, J.H.; Hu, Z.X.; Li, M.J.; Zheng, W.L.; Li, Z.J.; Pan, H.W. Quantitative proteomic analysis of human corneal epithelial cells infected with HSV-1. Exp. Eye Res. 2019, 185, 107664. [CrossRef]

120. Liu, H.; Huang, C.X.; He, Q.; Li, D.; Luo, M.H.; Zhao, F.; Lu, W. Proteomics analysis of HSV-1-induced alterations in mouse brain microvascular endothelial cells. J. Neurovirol. 2019, 25, 525-539. [CrossRef]

121. Wan, W.; Wang, L.; Chen, X.; Zhu, S.; Shang, W.; Xiao, G.; Zhang, L.K. A subcellular quantitative proteomic analysis of herpes simplex virus type 1-infected HEK 293T cells. Molecules 2019, 24, 4215. [CrossRef]

122. Gatto, L.; Breckels, L.M.; Lilley, K.S. Assessing sub-cellular resolution in spatial proteomics experiments. Curr. Opin. Chem. Biol. 2019, 48, 123-149. [CrossRef] [PubMed]

123. Jean Beltran, P.M.; Cook, K.C.; Cristea, I.M. Exploring and Exploiting Proteome Organization during Viral Infection. J. Virol. 2017, 91, 91. [CrossRef] [PubMed]

124. Jean Beltran, P.M.; Mathias, R.A.; Cristea, I.M. A Portrait of the Human Organelle Proteome In Space and Time during Cytomegalovirus Infection. Cell Syst. 2016, 3, 361-373.e6. [CrossRef] [PubMed] 
125. Rathore, D.; Nita-Lazar, A. Phosphoproteome Analysis in Immune Cell Signaling. Curr. Protoc. Immunol. 2020, 130, 130. [CrossRef]

126. Murray, L.A.; Sheng, X.; Cristea, I.M. Orchestration of protein acetylation as a toggle for cellular defense and virus replication. Nat. Commun. 2018, 9, 4967. [CrossRef]

127. Sloan, E.; Tatham, M.H.; Groslambert, M.; Glass, M.; Orr, A.; Hay, R.T.; Everett, R.D. Analysis of the SUMO2 Proteome during HSV-1 Infection. PLoS Pathog. 2015, 11, 130. [CrossRef]

128. Cai, Y.; Su, J.; Wang, N.; Zhao, W.; Zhu, M.; Su, S. Comprehensive analysis of the ubiquitome in rabies virus-infected brain tissue of Mus musculus. Vet. Microbiol. 2020, 241, 108552. [CrossRef]

129. Keller, A.; Chavez, J.D.; Eng, J.K.; Thornton, Z.; Bruce, J.E. Tools for 3D Interactome Visualization. J. Proteome Res. 2019, 18, 753-758. [CrossRef]

130. Liu, X.; Chang, C.; Han, M.; Yin, R.; Zhan, Y.; Li, C.; Ge, C.; Yu, M.; Yang, X. PPIExp: A Web-Based Platform for Integration and Visualization of Protein-Protein Interaction Data and Spatiotemporal Proteomics Data. J. Proteome Res. 2019, 18, 633-641. [CrossRef]

131. Michalak, W.; Tsiamis, V.; Schwämmle, V.; Rogowska-Wrzesińska, A. ComplexBrowser: A tool for identification and quantification of protein complexes in large-scale proteomics datasets. Mol. Cell. Proteom. 2019, 18, 2324-2334. [CrossRef]

132. Miryala, S.K.; Anbarasu, A.; Ramaiah, S. Discerning molecular interactions: A comprehensive review on biomolecular interaction databases and network analysis tools. Gene 2018, 642, 84-94. [CrossRef] [PubMed]

133. Rudolph, J.D.; Cox, J. A Network Module for the Perseus Software for Computational Proteomics Facilitates Proteome Interaction Graph Analysis. J. Proteome Res. 2019, 18, 2052-2064. [CrossRef] [PubMed]

134. Salamon, J.; Goenawan, I.H.; Lynn, D.J. Analysis and Visualization of Dynamic Networks Using the DyNet App for Cytoscape. Curr. Protoc. Bioinform. 2018, 63, e55. [CrossRef] [PubMed]

135. Choi, M.; Carver, J.; Chiva, C.; Tzouros, M.; Huang, T.; Tsai, T.H.; Pullman, B.; Bernhardt, O.M.; Hüttenhain, R.; Teo, G.C.; et al. MassIVE.quant: A community resource of quantitative mass spectrometry-based proteomics datasets. Nat. Methods 2020, 17, 981-984. [CrossRef]

136. Federspiel, J.D.; Cook, K.C.; Kennedy, M.A.; Venkatesh, S.S.; Otter, C.J.; Hofstadter, W.A.; Jean Beltran, P.M.; Cristea, I.M. Mitochondria and Peroxisome Remodeling across Cytomegalovirus Infection Time Viewed through the Lens of Inter-ViSTA. Cell Rep. 2020, 32. [CrossRef]

137. Goodwin, C.M.; Xu, S.; Munger, J. Stealing the Keys to the Kitchen: Viral Manipulation of the Host Cell Metabolic Network. Trends Microbiol. 2015, 23, 789-798. [CrossRef]

138. Shenk, T.; Alwine, J.C. Human cytomegalovirus: Coordinating cellular stress, signaling, and metabolic pathways. Annu. Rev. Virol. 2014, 1, 355-374. [CrossRef]

139. Xi, Y.; Harwood, S.; Wise, L.M.; Purdy, J.G. Human Cytomegalovirus pUL37x1 Is Important for Remodeling of Host Lipid Metabolism. J. Virol. 2019, 93, 843-862. [CrossRef]

140. Taylor, M.W. Interferons. In Viruses and Man: A History of Interactions; Springer International Publishing: Cham, Switzerland, 2014; pp. 101-119.

141. Schneider, W.M.; Chevillotte, M.D.; Rice, C.M. Interferon-stimulated genes: A complex web of host defenses. Annu. Rev. Immunol. 2014, 32, 513-545. [CrossRef]

142. Khan, M.M.; Koppenol-Raab, M.; Kuriakose, M.; Manes, N.P.; Goodlett, D.R.; Nita-Lazar, A. Host-pathogen dynamics through targeted secretome analysis of stimulated macrophages. J. Proteom. 2018, 189, 34-38. [CrossRef]

143. Bello-Morales, R.; Ripa, I.; López-Guerrero, J.A. Extracellular vesicles in viral spread and antiviral response. Viruses 2020, 12, 623. [CrossRef] [PubMed]

144. Miettinen, J.J.; Matikainen, S.; Nyman, T.A. Global Secretome Characterization of Herpes Simplex Virus 1-Infected Human Primary Macrophages. J. Virol. 2012, 86, 12770-12778. [CrossRef]

145. Pocock, J.M.; Storisteanu, D.M.L.; Reeves, M.B.; Juss, J.K.; Wills, M.R.; Cowburn, A.S.; Chilvers, E.R. Human cytomegalovirus delays neutrophil apoptosis and stimulates the release of a prosurvival secretome. Front. Immunol. 2017, 8, 8. [CrossRef] [PubMed]

146. Ni, X.; Ru, H.; Ma, F.; Zhao, L.; Shaw, N.; Feng, Y.; Ding, W.; Gong, W.; Wang, Q.; Ouyang, S.; et al. New insights into the structural basis of DNA recognition by HINa and HINb domains of IFI16. J. Mol. Cell Biol. 2016, 8, 51-61. [CrossRef] [PubMed]

147. Tian, Y.; Yin, Q. Structural analysis of the HIN1 domain of interferon-inducible protein 204. Acta Crystallogr. Sect. F Struct. Biol. Commun. 2019, 75, 455-460. [CrossRef] [PubMed] 
148. Brázda, V.; Coufal, J.; Liao, J.C.C.; Arrowsmith, C.H. Preferential binding of IFI16 protein to cruciform structure and superhelical DNA. Biochem. Biophys. Res. Commun. 2012, 422, 716-720. [CrossRef] [PubMed]

149. Hároníková, L.; Coufal, J.; Kejnovská, I.; Jagelská, E.B.; Fojta, M.; Dvoøáková, P.; Muller, P.; Vojtesek, B.; Brázda, V. IFI16 preferentially binds to DNA with quadruplex structure and enhances DNA quadruplex formation. PLoS ONE 2016, 11, e0157156. [CrossRef]

150. Morrone, S.R.; Wang, T.; Constantoulakis, L.M.; Hooy, R.M.; Delannoy, M.J.; Sohn, J. Cooperative assembly of IFI16 filaments on dsDNA provides insights into host defense strategy. Proc. Natl. Acad. Sci. USA 2014, 111, E62-E71. [CrossRef]

151. Civril, F.; Deimling, T.; De Oliveira Mann, C.C.; Ablasser, A.; Moldt, M.; Witte, G.; Hornung, V.; Hopfner, K.P. Structural mechanism of cytosolic DNA sensing by cGAS. Nature 2013, 498, 332-337. [CrossRef]

152. Gao, P.; Ascano, M.; Wu, Y.; Barchet, W.; Gaffney, B.L.; Zillinger, T.; Serganov, A.A.; Liu, Y.; Jones, R.A.; Hartmann, G.; et al. Cyclic $\left[\mathrm{G}\left(2^{\prime}, 5^{\prime}\right) \mathrm{pA}\left(3^{\prime}, 5^{\prime}\right) \mathrm{p}\right]$ is the metazoan second messenger produced by DNA-activated cyclic GMP-AMP synthase. Cell 2013, 153, 1094-1107. [CrossRef]

153. Zhou, W.; Whiteley, A.T.; de Oliveira Mann, C.C.; Morehouse, B.R.; Nowak, R.P.; Fischer, E.S.; Gray, N.S.; Mekalanos, J.J.; Kranzusch, P.J. Structure of the Human cGAS-DNA Complex Reveals Enhanced Control of Immune Surveillance. Cell 2018, 174, 300-311.e11. [CrossRef] [PubMed]

154. Li, X.; Shu, C.; Yi, G.; Chaton, C.T.; Shelton, C.L.; Diao, J.; Zuo, X.; Kao, C.C.; Herr, A.B.; Li, P. Cyclic GMP-AMP Synthase Is Activated by Double-Stranded DNA-Induced Oligomerization. Immunity 2013, 39, 1019-1031. [CrossRef] [PubMed]

155. Dremel, S.E.; Deluca, N.A. Herpes simplex viral nucleoprotein creates a competitive transcriptional environment facilitating robust viral transcription and host shut off. Elife 2019, 8, 8. [CrossRef] [PubMed]

156. Knipe, D.M.; Lieberman, P.M.; Jung, J.U.; McBride, A.A.; Morris, K.V.; Ott, M.; Margolis, D.; Nieto, A.; Nevels, M.; Parks, R.J.; et al. Snapshots: Chromatin control of viral infection. Virology 2013, 435, 141-156. [CrossRef]

157. Roy, A.; Ghosh, A.; Kumar, B.; Chandran, B. IfI16, a nuclear innate immune DNA sensor, mediates epigenetic silencing of herpesvirus genomes by its association with H3K9 methyltransferases SUV39H1 and GLP. Elife 2019, 8, 8. [CrossRef]

158. Abrisch, R.G.; Eidem, T.M.; Yakovchuk, P.; Kugel, J.F.; Goodrich, J.A. Infection by Herpes Simplex Virus 1 Causes Near-Complete Loss of RNA Polymerase II Occupancy on the Host Cell Genome. J. Virol. 2016, 90, 2503-2513. [CrossRef]

159. Lang, F.; Li, X.; Vladimirova, O.; Hu, B.; Chen, G.; Xiao, Y.; Singh, V.; Lu, D.; Li, L.; Han, H.; et al. CTCF interacts with the lytic HSV-1 genome to promote viral transcription. Sci. Rep. 2017, 7, 1-15. [CrossRef]

160. Bowman, G.D.; Poirier, M.G. Post-translational modifications of histones that influence nucleosome dynamics. Chem. Rev. 2015, 115, 2274-2295. [CrossRef]

161. Shivaswamy, S.; Bhinge, A.; Zhao, Y.; Jones, S.; Hirst, M.; Iyer, V.R. Dynamic remodeling of individual nucleosomes across a eukaryotic genome in response to transcriptional perturbation. PLoS Biol. 2008, 6, e65. [CrossRef]

162. Song, L.; Crawford, G.E. DNase-seq: A high-resolution technique for mapping active gene regulatory elements across the genome from mammalian cells. Cold Spring Harb. Protoc. 2010, 5. [CrossRef]

163. Giresi, P.G.; Kim, J.; McDaniell, R.M.; Iyer, V.R.; Lieb, J.D. FAIRE (Formaldehyde-Assisted Isolation of Regulatory Elements) isolates active regulatory elements from human chromatin. Genome Res. 2007, 17, 877-885. [CrossRef] [PubMed]

164. Buenrostro, J.D.; Giresi, P.G.; Zaba, L.C.; Chang, H.Y.; Greenleaf, W.J. Transposition of native chromatin for fast and sensitive epigenomic profiling of open chromatin, DNA-binding proteins and nucleosome position. Nat. Methods 2013, 10, 1213-1218. [CrossRef] [PubMed]

Publisher's Note: MDPI stays neutral with regard to jurisdictional claims in published maps and institutional affiliations.

(C) 2020 by the authors. Licensee MDPI, Basel, Switzerland. This article is an open access article distributed under the terms and conditions of the Creative Commons Attribution (CC BY) license (http://creativecommons.org/licenses/by/4.0/). 